\title{
Monika Korolewska Samorządowe dochody podatkowe w wybranych państwach Unii Europejskiej
}

Local government revenues in selected EU member states

The article looks at the issue of local taxation in 22 selected European countries, members of OECD, as well as the European Union member states. The author analyses the importance of local taxes for regional and local governments measured by the share of tax revenues received by these governments as a percentage of GDP and percentage of total tax revenues. She also presents the structure of local tax revenues. The study is based on the OECD revenue and taxes in Europe database.

\begin{tabular}{r|l}
\hline DOI & https://doi.org/10.31268/StudiaBAS.2021.13 \\
\hline Słowa kluczowe & $\begin{array}{l}\text { Unia Europejska, podatki lokalne, dochody podatkowe, dochody } \\
\text { własne }\end{array}$ \\
\hline Keywords & European Union, local taxes, tax revenues, own revenue \\
\hline O autorce & $\begin{array}{l}\text { specjalista ds. finansów publicznych w Biurze Analiz Sejmowych • } \\
\text { monika.korolewska@sejm.gov.pl • ORCID 0000-0002-6802-2367 }\end{array}$ \\
\hline
\end{tabular}

\section{Wstęp}

Nie ma powszechnie obowiązującej definicji podatków samorządowych, a samorządowe dochody podatkowe są różnie definiowane w zależności od państwa. Wprawdzie w literaturze przedmiotu formułuje się pewne definicje podatków samorządowych, są to jednak rozważania czysto teoretyczne, które nie znajdują odzwierciedlenia w rzeczywistości. Przykładowo w opinii R. Birda o podatku w pełni lokalnym można mówić wtedy, kiedy władze lokalne mają: 1) swobodę w nakładaniu podatku, 2) prawo do stanowienia podstawy opodatkowania, 3) prawo do określania stawki podatkowej, 4) w przypadku opodatkowania bezpośredniego - prawo do ustalenia wymiaru podatku w odniesieniu do każdego podatnika, 5) prawo do administrowania podatkiem, 6) prawo do całości dochodów osiąganych z podatku ${ }^{1}$. W realnym świecie wiele podatków samorządowych spełnia tylko pewną część tych warunków, a zdarza się, że jedynie jeden.

W piśmiennictwie rozpatruje się podatki samorządowe także od strony negatywnych skutków, jakich nie powinny przynosić. Mianowicie w następstwie funkcjonowania określonego podatku samorządowego nie powinno dochodzić do: zakłócenia alokacji zasobów, drapieżnej konkurencji podatkowej ani pionowej i poziomej nierównowagi fiskalnej. Ponadto podatki samorządowe powinny być łatwe do administrowania i egzekwowania. W rzeczywistości jednak raczej nie ma podatku, który spełniłby wszystkie powyższe oczekiwania². Każde państwo członkowskie Unii Europejskiej zatem różnie definiuje podatki samorządowe.

1 R.M. Bird, R. Bahl, Subnational Taxes in Developing Countries. The Way Forward, "IIB Paper" 2008, nr 16, s. 8.

2 M.F. Ambrosiano, M. Bordignon, Normative Versus Positive Theories of Revenue Assignments in Federations [w:] Handbook of Fiscal Federalism, red. E. Ahmad, G. Brosio, Edward Elgar, Cheltenham-Massachusetts 2006, s. 326. 
Brak przejrzystości w samym definiowaniu podatków samorządowych sprawia, że utrudnione staje się porównywanie rozwiązań z zakresu samorządowych dochodów podatkowych obowiązujących w poszczególnych państwach członkowskich UE. Sytuację komplikuje dodatkowo to, że dochody te są bardzo zróżnicowane. Ustanawianie podatków samorządowych w państwach Unii nie tylko odbywa się w oparciu o różne źródła opodatkowania - jakkolwiek dominujące znaczenie mają: opodatkowanie dochodów, majątku oraz dóbr i usług - lecz także zasadza się na jednej formie z trzech. Pierwsza to uchwalanie podatków własnych, które są regulowane i administrowane przez władze samorządowe. Druga polega na ustanawianiu samorządowych dodatków do podatków ogólnokrajowych. Trzecią formę stanowi dzielenie wpływów z określonego podatku między władzę centralną i władzę samorządową. Wymienione formy różni stopień autonomii finansowej i władztwa podatkowego samorządu terytorialnego ${ }^{3}$. Co więcej, podatki dzielone są często pod względem prawnym zrównane z podatkami własnymi. Jednocześnie podatki dzielone nierzadko trudno jest odróżnić od transferów z budżetu centralnego dofinansowujących funkcjonowanie samorządu terytorialnego. $Z$ jednej strony wiele formuł podziału podatków wydaje się skomplikowane i nie jest jasny związek między tym, jakie wpływy podatkowe są generowane na terytorium samorządu terytorialnego oraz jakie kwoty trafiają do wspólnej puli, a tym, co w końcu wraca do budżetu samorządu. Z drugiej strony transfery z budżetu centralnego mogą przypominać udział w krajowych wpływach podatkowych. W efekcie to, co liczy się jako udział w podatkach w jednym państwie, może stanowić transfer międzysektorowy w innym. Ponadto w niektórych państwach różne organy mogą mieć odmienne podejście do klasyfikowania dochodów samorządu terytorialnego ${ }^{4}$.

Obok braku jednolitego podejścia państw europejskich do wyznaczenia zakresu podatków samorządowych porównanie samorządowych dochodów podatkowych w państwach członkowskich UE jest utrudnione także przez to, że zasady stanowienia rachunków narodowych oraz międzynarodowych statystyk dochodów nie są precyzyjne.

Nawet w obliczu wskazanych ułomności metodologicznych porównanie samorządowych dochodów podatkowych w państwach członkowskich UE może mieć wysokie walory poznawcze. Artykuł stanowi próbę dokonania takiego zestawienia z użyciem metod zarówno oceny ilościowej, jak i oceny jakościowej.

Wykorzystanie metod ilościowych pozwoli na analizę roli fiskalnej podatków samorządowych oraz struktury dochodów z tych podatków. W tym celu autorka posłuży się danymi OECD dostępnymi w Revenue Statistics 2020. Tym samym prowadzona komparacja nie obejmie wszystkich państw członkowskich UE, lecz będzie dotyczyła jedynie tych, które jednocześnie są członkami OECD. Należą do nich: Austria, Belgia, Czechy, Dania, Estonia, Finlandia, Francja, Grecja, Hiszpania, Holandia (Niderlandy), Irlandia, Litwa, Łotwa, Niemcy, Polska, Portugalia, Słowacja, Słowenia, Szwecja, Węgry i Włochy. Ponadto do grupy badanych państw dołączono Wielką Brytanię. Ze względu na dobór źródła danych statystycznych w przypadku państw federacyjnych, do których zostały zaliczone trzy państwa o ustroju federalnym (Austria, Belgia, Niemcy) oraz jedno zregionalizowane

Ibidem, s. 323.

4 H. Blöchliger, O. Petzold, Finding the Dividing Line Between Tax Sharing and Grants. A Statistical Investigation, „OECD Working Papers on Fiscal Federalism” 2009, nr 10, s. 3, https://doi.org/10.1787/5k97b10vvbnw-en. 
państwo o strukturze quasi-federacyjnej (Hiszpania), analiza będzie prowadzona w podziale na samorząd regionalny i samorząd lokalny ${ }^{5}$. W przypadku pozostałych państw samorząd lokalny obejmuje wszystkie szczeble samorządu terytorialnego funkcjonujące w danym państwie. Wykorzystanie metody jakościowej pozwoli przedstawić faktyczne aspekty funkcjonowania podatków samorządowych w poszczególnych państwach. W analizach oparto się głównie na danych zawartych w studium OECD - Subnational Governments Around the World. Structure and Finance, w bazie Komisji Europejskiej - Taxes in Europe Database v3 oraz w publikacji Local Public Finance in Europe ${ }^{6}$.

\section{Znaczenie samorządowych dochodów podatkowych}

Trudno jest ustalić stosowne miary, które pozwoliłyby dokonać pełnego porównania znaczenia samorządowych dochodów podatkowych w państwach członkowskich UE. Wskaźniki statystyczne powinny mieć jak najbardziej uniwersalny charakter. Jednakże nawet w przypadku tych wskaźników, z uwagi na różne klasyfikowanie wpływów podatkowych w dochodach samorządowych, należy się liczyć z występowaniem różnic w porównywalności danych. Stąd dla właściwszej interpretacji danych statystycznych zostanie również dokonana porównawcza analiza jakościowa samorządowych dochodów podatkowych w wybranych państwach członkowskich UE. W kontekście tej analizy doniosłe znaczenie mogą mieć szczególnie pozycja ustrojowa samorządu terytorialnego oraz konstrukcja systemu podatkowego. Rozwiązania w systemie zarządzania państwem wpływają bowiem na określenie roli samorządu terytorialnego poszczególnych szczebli w realizacji zadań publicznych, do których wykonywania niezbędne są odpowiednie środki finansowe. Z kolei konstrukcja systemu podatkowego rzutuje na sposób alokacji poszczególnych podatków pomiędzy władzę centralną i władze samorządowe oraz ma wpływ na zakres władztwa podatkowego przyznawanego samorządom.

Do oceny znaczenia samorządowych dochodów podatkowych w wybranych państwach europejskich zostały wybrane dwa wskaźniki statystyczne: udział dochodów podatkowych poszczególnych sektorów w produkcie krajowym brutto oraz udział dochodów podatkowych sektora samorządowego w dochodach podatkowych ogółem. Ze względu na zakres tematyczny artykułu w analizie nie uwzględniono miernika opisującego udział wydatków sektora samorządowego w produkcie krajowym brutto, który także należycie przedstawia rolę samorządu terytorialnego w sferze działań publicznych. Wysoki poziom wydatków samorządowych nie musi jednak świadczyć o istotnej roli samorządowych dochodów podatkowych, w sytuacji gdy samorządowa gospodarka finansowa opiera się głównie na transferach z budżetu państwa7.

Z danych o udziale samorządowych dochodów podatkowych w PKB wynika, że w 2018 r. W sześciu analizowanych państwach samorządowe dochody podatkowe nie stanowiły nawet 1\% PKB. Było tak: w Estonii (0,3\%), w Czechach i na Litwie (0,4\%), w Irlandii (0,5\%), Słowacji

5 A. Błaszko, Organizacja samorzqdu terytorialnego oraz nadzoru nad samorzadem we Francji, „Finanse Komunalne" 2019, nr 6, s. 63.

6 Local Public Finance in Europe. Country Reports, red. R. Geißler, G. Hammerschmid, Ch. Raffer, Bertelsmann Stiftung, Gütersloh 2019.

7 Ibidem. 
Wykres 1. Udział dochodów podatkowych w PKB według sektorów w 2018 r.

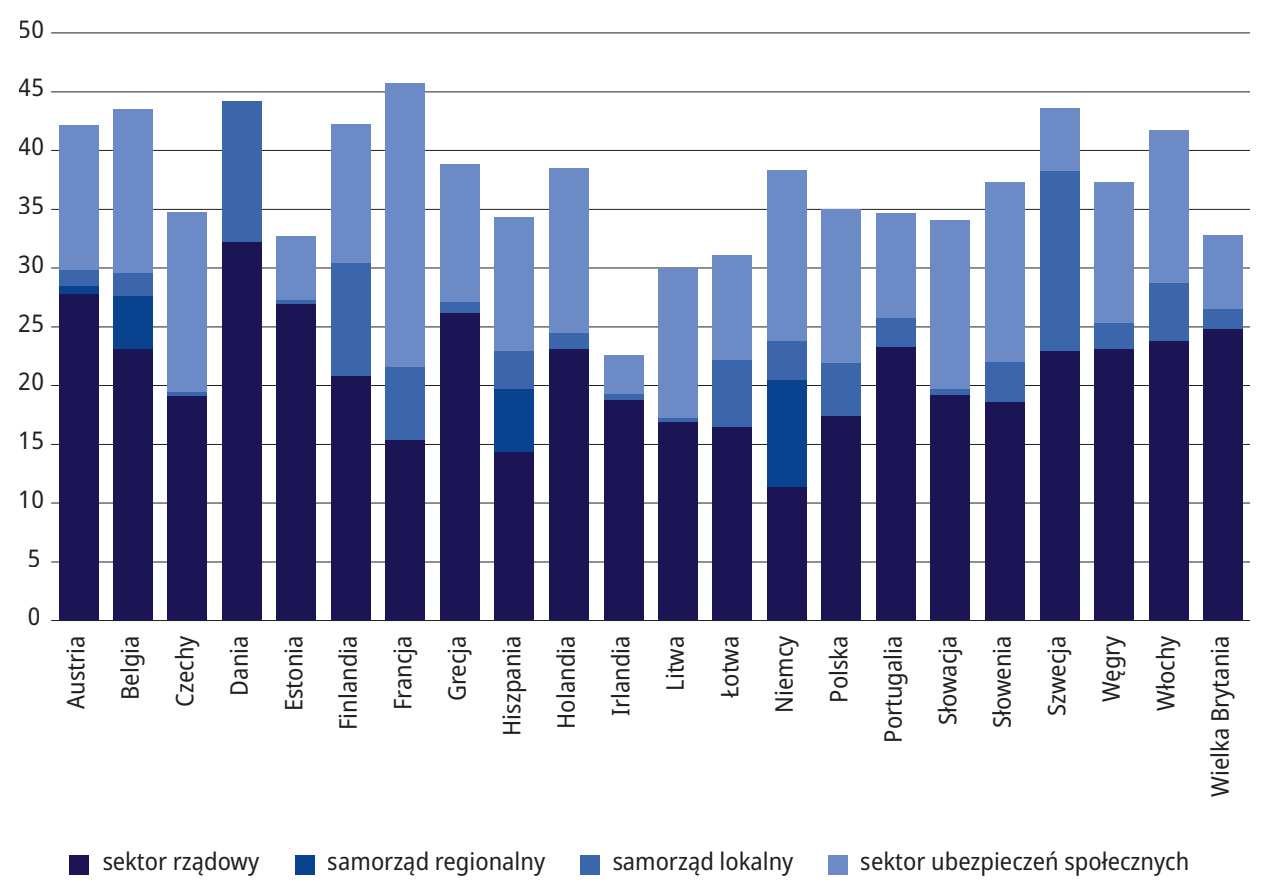

Źródło: opracowanie własne na podstawie OECD, Revenue Statistics 2020.

$(0,6 \%)$ oraz Grecji $(0,9 \%)$. W grupie sześciu państw udział samorządowych dochodów podatkowych w PKB kształtował się na poziomie powyżej 1\%, ale poniżej 4\%. Należały do niej: Holandia $(1,4 \%)$, Wielka Brytania (1,7\%), Austria (2\%), Węgry (2,2\%), Portugalia (2,5\%) i Słowenia (3,4\%). W kolejnych pięciu państwach udział ten nie przekroczył 7\% (Polska - 4,5\%, Włochy - 4,9\%, Łotwa - 5,7\%, Francja - 6,2\% i Belgia - 6,5\%). Najwyższa relacja samorządowych dochodów podatkowych do PKB cechowała trzy państwa skandynawskie oraz dwa państwa federacyjne, przy tym wskaźnik udziału na poziomie powyżej 10\% odnotowano jedynie w Szwecji i Danii (odpowiednio 15,4\% oraz 12\%), a także w Niemczech (12,4\%). W Finlandii i Hiszpanii relacja ta była nieco niższa i wynosiła odpowiednio $9,6 \%$ oraz $8,5 \%$.

Do podobnych wniosków prowadzi także analiza udziału dochodów podatkowych sektora samorządowego w dochodach podatkowych ogółem. W grupie państw o najniższym udziale znalazły się bowiem: Estonia, Czechy, Litwa, Słowacja, Irlandia i Grecja. We wszystkich tych państwach wskaźnik udziału dochodów podatkowych sektora samorządowego w dochodach podatkowych ogółem nie przekroczył 3\%. Kolejną grupę stanowiły te państwa, w których analizowana relacja nie osiągnęła 10\%. Należały do niej: Holandia, Austria, Wielka Brytania, Węgry, Portugalia i Słowenia. Następną grupę tworzyły państwa, w których wskaźnik nie przekroczył 20\%, a zatem: Włochy, Polska, Francja, Belgia i Łotwa. W pięciu państwach relacja dochodów 
Wykres 2. Udział dochodów podatkowych sektora samorządowego w dochodach podatkowych ogółem w 2018 r.

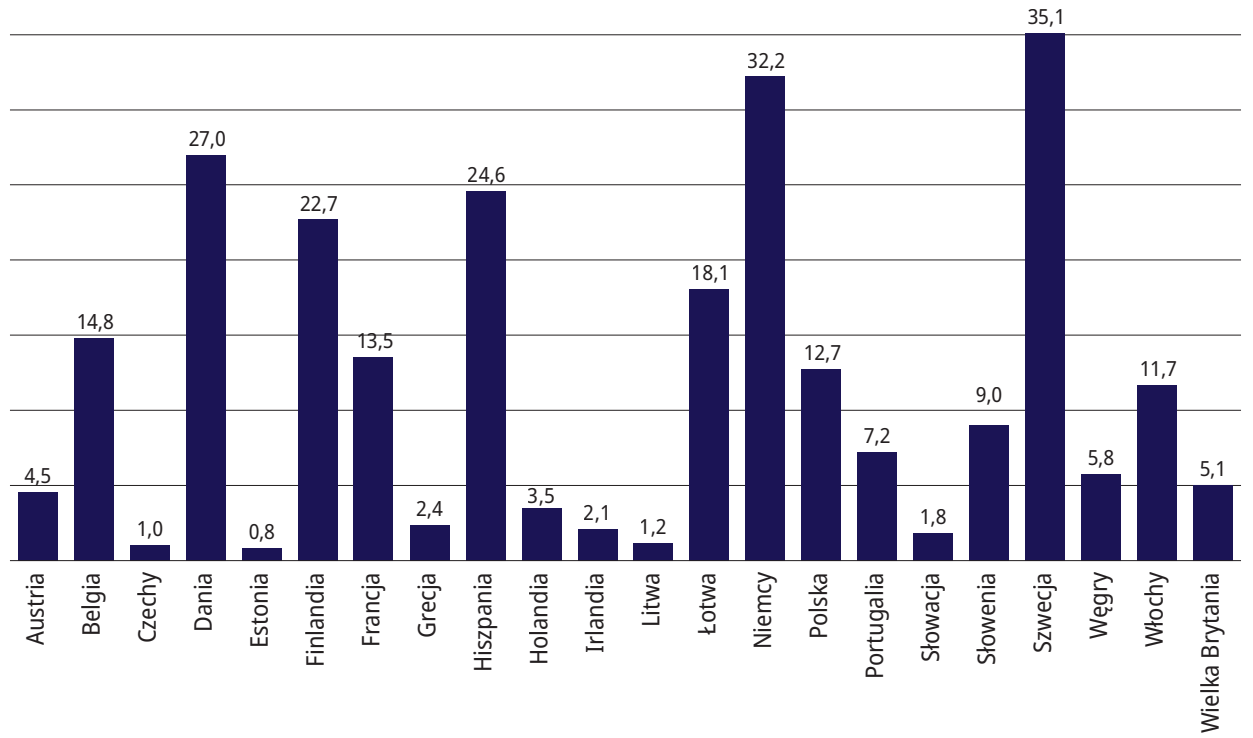

Źródło: opracowanie własne na podstawie OECD, op. cit.

podatkowych sektora samorządowego do dochodów podatkowych ogółem przekraczała tę granicę, przy tym w dwóch państwach - w Niemczech i Szwecji - wynosiła ponad 30\%.

Jak już zauważono wcześniej przy okazji badań porównawczych, w których zestawia się ze sobą rozwiązania obowiązujące w kilkudziesięciu państwach, szczególną uwagę należy poświęcić budowie mierników i ich interpretacji ${ }^{8}$. Przy interpretacji dwóch wspomnianych wskaźników należy pamiętać, że samorządowe dochody podatkowe są różnie definiowane w zależności od państwa. Niektóre państwa określają jako samorządowe dochody podatkowe te podatki, względem których władze samorządowe mają prawo do kształtowania stawek podatkowych lub/i podstawy opodatkowania. Inne państwa, definiując samorządowe dochody podatkowe, nie uwzględniają kwestii władztwa podatkowego władz samorządowych. Szczególnie ważne w tym kontekście są ustalenia dotyczące podziału podatków pomiędzy władze centralne i władze samorządowe. Zgodnie z danymi OECD zawartymi w Revenue Statistics niektóre państwa zaliczają dochody z podatków dzielonych do samorządowych dochodów podatkowych (np. Niemcy, Polska), podczas gdy inne uznają je za transfery międzysektorowe (np. Estonia, Litwa). Jest to istotne zwłaszcza przy uznawaniu udziałów samorządu terytorialnego w podatku docho-

8 B. Guziejewska, Normative Versus Positive Approach to Fiscal Decentralisation and the Measures of Decentralisation. An Analysis Based on the Example of Selected Countries of Central and Eastern Europe, "Comparative Economic Research" 2018, t. 21, nr 1, s. 110. 
dowym od osób fizycznych (dalej: PIT) bądź innych wydajnych fiskalnie podatkach, np. podatku dochodowym od osób prawnych (dalej: CIT) oraz podatku od towarów i usług (dalej: VAT). Brak spójności klasyfikacyjnej w tym przypadku ma bardzo duże znaczenie, gdyż w wielu państwach dochody z tych podatków dzielonych stanowią znaczącą część dochodów samorządowych. Można przytoczyć wiele przykładów na potwierdzenie tej opinii.

W pierwszej kolejności należy zauważyć, że w Estonii, w której relacje samorządowych dochodów podatkowych do PKB oraz do dochodów podatkowych ogółem są najniższe, de facto ponad 90\% dochodów podatkowych samorządu lokalnego pochodzi z udziałów w PIT. Jednak wpływy z tego tytułu zostały przeklasyfikowane na transfery międzysektorowe kierowane do budżetów samorządowych przy okazji wprowadzenia w 2014 r. Systemu Rachunków Narodowych. Obecnie (od 1 stycznia 2020 r.) równowartość 11,96\% podlegającego opodatkowaniu dochodu osoby fizycznej będącej rezydentem jest przekazywana do budżetu samorządu lokalnego. Pozostała część podatku dochodowego i podatku dochodowego od emerytur i zysków z przeniesienia własności trafia do sektora rządowego ${ }^{9}$. Dochody tego sektora z tytułu PIT są pomniejszone o obowiązujące odliczenia, stąd rząd centralny może znaleźć się w paradoksalnej sytuacji, w której musiałby przenieść do budżetów gmin więcej środków w związku z PIT, niż faktycznie pobrał. Przy obowiązującej stawce PIT w wysokości $20 \%$ do budżetów gminy w praktyce trafia $80 \%$ całkowitego dochodu z tego podatku ${ }^{10}$.

Podobnie jest na Litwie, gdzie podatkiem dzielonym jest także podatek dochodowy od osób fizycznych, który od 2014 r. jest klasyfikowany jako transfer. W 2020 r. 53,79\% wszystkich dochodów z PIT trafiało do budżetu państwa, a 46,21\% - do budżetów gmin (w tym 42,84\% jako część stała, a 3,10\% jako część zmienna), podczas gdy w 2019 r. udział w PIT przypadający na budżety wszystkich gmin wynosił 46,88\% (z tego część stała - 42,78\%, część zmienna - 4,10\%). Proporcje podziału podatku dochodowego od osób fizycznych między budżet państwa i budżety gmin są określone corocznie w ustawie zatwierdzającej wskaźniki budżetu państwa i budżetów gminnych Republiki Litewskiej. Ustawa ta zawiera także listę udziałów przydzielonych każdej z gmin ${ }^{11}$.

Również do słowackich regionów i gmin trafiają dochody z opodatkowania dochodów osób fizycznych, jakkolwiek elementy konstrukcyjne PIT - stawki, podstawa opodatkowania oraz ulgi - są ustanawiane przez organy centralne. Regiony otrzymują 30\% dochodów z podatku dochodowego od osób fizycznych (bez podatku pobieranego u źródła), a gminy 70\% tych dochodów (bez podatku pobieranego u źródła) ${ }^{12}$. Wpływy z tego tytułu nie są jednak klasyfikowane jako samorządowe dochody podatkowe.

W innych państwach, w których podobnie jak w Estonii oraz na Litwie i w Słowacji władze dzielą się dochodami z PIT z władzami samorządowymi, udział samorządu terytorialnego

9 European Commission, Taxes in Europe Database v3, https://ec.europa.eu/taxation_customs/tedb/taxDetails. html?id=205/1577833200\#footnote1 [dostęp: 23 kwietnia 2021 r.].

10 Local Public..., s. 73.

11 Republic of Lithuania Law on the Approval of Financial Indicators of the State Budget and Municipal Budgets for 2019, http://finmin.Irv.It/uploads/finmin/documents/files/2018-12-11\%20XIII-1710.pdf [dostęp: 22 kwietnia 2021 r.].

12 European Commission, op. cit. 
w podatku dochodowym od osób fizycznych spełnia warunki, aby podatek ten traktować jako „podatek własny”. Przykładem może tu być rząd słoweński, który stoi na takim stanowisku, i to nawet w sytuacji, gdy rozdysponowanie udziału w PIT jest powiązane z bieżącymi potrzebami wydatkowymi gmin. Takie podejście rządu opiera się na postanowieniu Sądu Konstytucyjne$\mathrm{go}^{13}$. Zgodnie z decyzją sądu środki własne gmin są bezpośrednio powiązane z gminą, dlatego należy te JST uznać za bezpośrednich beneficjentów podatku dochodowego od osób fizycznych, nawet jeśli - technicznie rzecz biorąc - podatek jest pobierany przez państwo. Podobną sytuację z podatkiem dochodowym od osób fizycznych obserwuje się na Łotwie, gdzie podatek jest pobierany przez państwo, ale obejmuje znaczną część dochodu gminy.

Także w Czechach, w których wskaźniki udziału samorządowych dochodów podatkowych w PKB oraz w dochodach podatkowych ogółem należą do najniższych, faktyczne znaczenie dochodów podatkowych jest większe, niż to wynika z analizy obu tych mierników. Mianowicie w Czechach jednym z najważniejszych źródeł dochodów samorządowych jest zbiór podatków wspólnych, które są pobierane i rozdzielane centralnie. Zbiór ten obejmuje: PIT, CIT, VAT oraz podatek dochodowy od osób samozatrudnionych. Schemat dystrybucji środków pochodzących z podatków wspólnych opiera się na kryteriach ilościowych, takich jak liczba mieszkańców i wielkość gminy ${ }^{14}$. Jeśli uwzględnić dochody z podatków wspólnych oraz z podatków samorządowych, to wpływy podatkowe stanowiły w 2018 r. ponad 45\% dochodów samorządu ogółem. Zbliżona sytuacja występuje w Austrii, która na tle innych państw federalnych osiąga najniższe wskaźniki relacji samorządowych dochodów podatkowych do PKB i do dochodów podatkowych ogółem. W Austrii, podobnie jak w Czechach, to właśnie udział w łącznych wpływach podatkowych stanowi najważniejsze źródło dochodów gmin, co jednak nie znajduje odzwierciedlenia w analizowanych wskaźnikach. Wśród podatków, które obejmuje lista podatków dzielonych między austriackie władze centralne i samorządowe, najistotniejsze są: VAT, PIT, CIT oraz podatek od ropy naftowej. Podział dochodów podatkowych między federację, kraje związkowe (landy) i gminy jest regulowany przez ustawodawstwo federalne, ustanawiające przepisy dotyczące kwestii wyrównywania finansowego. W Niemczech, gdzie również większość dochodów podatkowych krajów związkowych (landów) pochodzi z podatków dzielonych (głównie z PIT, CIT i VAT), a w przypadku samorządów lokalnych źródłem znacznej części dochodów podatkowych są udziały w PIT, podatku od zysków kapitałowych (od odsetek) i VAT, wszystkie tego rodzaju wpływy są zaliczane do samorządowych dochodów podatkowych i tym samym zostały uwzględnione w analizowanych miernikach statystycznych.

\section{Struktura samorządowych dochodów podatkowych}

W tradycyjnej teorii federalizmu fiskalnego podaje się kilka wytycznych odnośnie do podatków, które powinny wpływać do budżetów samorządowych. Zgodnie z zaleceniami podatki samorządowe powinny być nakładane na takie przedmioty opodatkowania, które są stosunkowo

13 Postanowienie nr U-I-150/15 z 10 listopada 2016 r.
14 Local Public..., s. 41. 
nieruchome, dość równomiernie rozmieszczone oraz w przypadku których jest wysoce prawdopodobne, że będą przynosić stabilne dochody ${ }^{15}$. Wymienione zasady sprowadzają się do tego, że samorządy na szczeblu lokalnym powinny czerpać dochody przede wszystkim z opłat za usługi publiczne i podatków od nieruchomości. Dla samorządów regionalnych właściwe byłoby opodatkowanie sprzedaży, pod warunkiem że obejmowałoby ono dostatecznie rozległe obszary, aby wykluczyć ucieczkę przed podatkiem. Wskazane mogłoby być także opodatkowanie dochodów osób fizycznych, ale z tym zastrzeżeniem, że miałoby ono lekko progresywny charakter. Do wyłącznych kompetencji władz szczebla centralnego powinno natomiast należeć opodatkowanie dochodów ze wszystkich źródeł ${ }^{16}$. Istnieje kilka istotnych przeszkód w praktycznym stosowaniu powyższych naukowych zasad przy kształtowaniu dochodów podatkowych samorządu terytorialnego. Po pierwsze, usługi publiczne świadczone przez samorządy często przynoszą ogólne korzyści, które trudno jest ściśle powiązać z podatkami od beneficjentów. Po drugie, samorząd terytorialny w praktyce często sprawuje funkcje redystrybucyjne, które co do zasady nie mogą być finansowane z podatków nakładanych w związku ze świadczonymi usługami publicznymi. Ponadto dochody z opłat za usługi publiczne wraz z podatkami od nieruchomości mogą być niewystarczające do pokrycia wszystkich wydatków samorządowych ${ }^{17}$. Dlatego w praktyce samorządy terytorialne opierają się na różnego rodzaju opodatkowaniu, przede wszystkim na podatkach majątkowych, podatkach od dochodów osobistych oraz podatkach nakładanych na dobra i usługi.

Ze względu na strukturę samorządowych dochodów podatkowych analizowane w artykule państwa członkowskie Unii Europejskiej można podzielić na trzy grupy.

Pierwszą grupę stanowią te państwa, w których liczba źródeł dochodów podatkowych jest niewielka, a większość wpływów jest osiągana z jednego rodzaju podatków. Najbardziej skrajny przypadek stanowi Wielka Brytania, w której dochody podatkowe samorządu terytorialnego pochodzą wyłącznie z opodatkowania nieruchomości. W Anglii, Szkocji i Walii obowiązuje podatek lokalny council tax, który jest lokalnym podatkiem od nieruchomości znajdujących się na terenie Wielkiej Brytanii, pobieranym przez władze lokalne, tzw. county councils. Z podatku tego są finansowane: lokalne szkoły, biblioteki, policja, straż pożarna, wywóz śmieci itd. ${ }^{18}$

Jeszcze w kilku innych państwach głównym źródłem samorządowych dochodów podatkowych jest opodatkowanie nieruchomości, ale samorządy korzystają również z innego typu podatków, by osiągać dochody podatkowe. Tak jest w Grecji, w Estonii i na Litwie, gdzie uzupełnieniem dochodów podatkowych z opodatkowania nieruchomości są wpływy związane z opodatkowaniem dóbr i usług, oraz w Irlandii, gdzie poza opodatkowaniem nieruchomości dochody podatkowe samorządu terytorialnego pochodzą ze składek na ubezpieczenie społecz-

15 R.M. Bird, Rethinking Subnational Taxes. A New Look at Tax Assignment, „IMF Working Paper” 1999, nr 165, s. 4, https://doi.org/10.5089/9781451858037.001.

16 Federalizm fiskalny w teorii i praktyce, red. K. Piotrowska-Marczak, Difin, Warszawa 2009, s. 28.

17 M.F. Ambrosiano, M. Bordignon, op. cit., s. 326.

18 K.A. Kopyściańska, Podatek katastralny w kontekście konstytucyjnej zasady sprawiedliwości, „Annales Universitatis Mariae Curie-Skłodowska. Sectio H. Oeconomia" 2016, t. 50, nr 1, s. 385, http://doi. org/10.17951/h.2016.50.1.381. 
Tabela 1. Struktura dochodów podatkowych sektora samorządowego w 2018 r.

\begin{tabular}{|c|c|c|c|c|c|c|}
\hline & 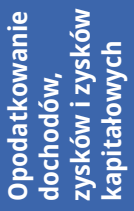 & 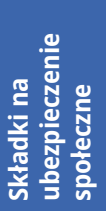 & 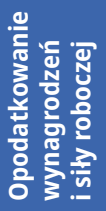 & 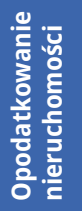 & 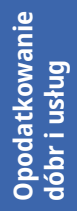 & 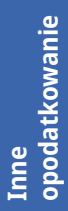 \\
\hline \multicolumn{7}{|l|}{ Austria } \\
\hline samorząd regionalny & 48,7 & 18,9 & 9,1 & 1,8 & 17,5 & 4,0 \\
\hline samorząd lokalny & 0,0 & 5,2 & 69,5 & 14,8 & 7,6 & 2,9 \\
\hline \multicolumn{7}{|l|}{ Belgia } \\
\hline samorząd regionalny & 45,8 & 1,2 & 0,0 & 38,3 & 14,6 & 0,0 \\
\hline samorząd lokalny & 35,0 & 0,2 & 0,0 & 57,3 & 7,5 & 0,0 \\
\hline Czechy & 0,0 & 0,0 & 0,0 & 56,9 & 43,1 & 0,0 \\
\hline Dania & 89,0 & 0,0 & 0,0 & 11,0 & 0,0 & 0,0 \\
\hline Estonia & 0,0 & 0,0 & 0,0 & 81,7 & 18,3 & 0,0 \\
\hline Finlandia & 91,9 & 0,0 & 0,0 & 8,1 & 0,0 & 0,0 \\
\hline Francja & 0,0 & 0,0 & 7,2 & 50,9 & 34,9 & 6,9 \\
\hline Grecja & 0,0 & 0,0 & 0,0 & 93,6 & 6,4 & 0,0 \\
\hline \multicolumn{7}{|l|}{ Hiszpania } \\
\hline samorząd regionalny & 68,0 & 0,0 & 0,0 & 19,9 & 12,1 & 0,0 \\
\hline samorząd lokalny & 17,9 & 0,0 & 0,0 & 44,4 & 37,6 & 0,1 \\
\hline Holandia & 0,0 & 0,0 & 0,0 & 52,4 & 47,6 & 0,0 \\
\hline Irlandia & 0,0 & 9,9 & 0,0 & 90,1 & 0,0 & 0,0 \\
\hline Litwa & 0,0 & 0,0 & 0,0 & 84,9 & 15,1 & 0,0 \\
\hline Łotwa & 85,1 & 0,0 & 0,0 & 13,6 & 1,3 & 0,0 \\
\hline \multicolumn{7}{|l|}{ Niemcy } \\
\hline samorząd regionalny & 53,1 & 0,0 & 0,0 & 6,8 & 40,1 & 0,0 \\
\hline samorząd lokalny & 79,0 & 0,0 & 0,0 & 12,8 & 8,0 & 0,2 \\
\hline Polska & 65,1 & 0,0 & 0,0 & 29,3 & 4,4 & 1,1 \\
\hline Portugalia & 25,0 & 0,0 & 0,0 & 48,4 & 26,5 & 0,1 \\
\hline Słowacja & 0,0 & 0,0 & 0,0 & 65,7 & 34,3 & 0,0 \\
\hline Słowenia & 76,1 & 0,0 & 0,0 & 17,8 & 6,0 & 0,0 \\
\hline Szwecja & 97,6 & 0,0 & 0,0 & 2,4 & 0,0 & 0,0 \\
\hline Węgry & 0,0 & 0,0 & 0,0 & 17,8 & 82,1 & 0,0 \\
\hline Włochy & 19,2 & 0,0 & 0,0 & 22,2 & 30,8 & 27,7 \\
\hline Wielka Brytania & 0,0 & 0,0 & 0,0 & 100,0 & 0,0 & 0,0 \\
\hline
\end{tabular}

Źródło: opracowanie własne na podstawie OECD, op. cit. 
ne. W przypadku Estonii i Litwy najistotniejszym źródłem dochodów podatkowych są udziały w PIT, które klasyfikuje się tam jako transfery międzysektorowe.

W kolejnych kilku państwach z pierwszej grupy dominującym źródłem samorządowych dochodów podatkowych jest opodatkowanie dochodów, zysków i zysków kapitałowych, które w niewielkim stopniu jest dopełniane wpływami z opodatkowania nieruchomości. Taka sytuacja występuje w trzech państwach skandynawskich: Danii, Finlandii i Szwecji. Także na Łotwie i w Słowenii dochody podatkowe sektora samorządowego stanowi głównie opodatkowanie dochodów, ale dopełniają je dochody podatkowe z dwóch innych rodzajów podatków - z opodatkowania nieruchomości oraz z opodatkowania dóbr i usług. Odosobniony przypadek w tej grupie państw stanowią Węgry, gdzie samorządowe dochody podatkowe w pierwszej kolejności pochodzą z opodatkowania dóbr i usług, które dopełnia opodatkowanie nieruchomości.

W drugiej grupie znajdują się państwa, w których samorządowe dochody podatkowe pochodzą wyłącznie z dwóch rodzajów podatków, przy tym żadne z tych źródeł znacząco nie przeważa. Taka sytuacja charakteryzuje Czechy, Holandię i Słowację. W tych państwach ponad połowa samorządowych dochodów podatkowych pochodzi z opodatkowania nieruchomości, pozostała zaś część - z opodatkowania dóbr i usług. W przypadku Czech i Słowacji istotne znaczenie fiskalne mają także transfery częściowo powiązane z dochodami podatkowymi, m.in. z PIT, które do celów statystycznych nie są ujęte jako dochody podatkowe.

Trzecią grupę stanowią państwa, w których źródłem samorządowych dochodów podatkowych są bardzo zróżnicowane podstawy opodatkowania. Grupa ta obejmuje z jednej strony państwa federalne: Austrię, Belgię, Niemcy, i państwo quasi-federalne - Hiszpanię, z drugiej strony - państwa unitarne: Francję, Portugalię i Włochy. Jakkolwiek wpływy z jednego typu opodatkowania (bądź dwóch) górują nad pozostałymi, w praktyce rozkład źródeł opodatkowania stanowiących podstawę finansowania regionalnych i lokalnych samorządów w tych państwach jest odmienny.

Austrię na tle pozostałych państw wyróżnia to, że jedynie tam samorząd lokalny większość dochodów podatkowych osiąga z opodatkowania wynagrodzeń i siły roboczej. W Austrii bowiem mianem podatku samorządowego można określić przede wszystkim podatek gminny (Kommunalsteuer), który jest swego rodzaju podatkiem od działalności gospodarczej. Jest on naliczany od sumy wynagrodzeń w przedsiębiorstwie. Stawka podatkowa wynosi 3\% i jest ustalana na szczeblu federalnym. Za drugi najbardziej znaczący podatek samorządowy można uznać podatek od nieruchomości, który jednak pod względem fiskalnym odgrywa znacznie mniejszą rolę. Każda gmina ustanawia własny podatek od nieruchomości. Ze względu na to, że podstawa opodatkowania podatkiem od nieruchomości nie była korygowana od 1973 r., obecnie trwa reforma tego podatku. W skali kraju dochody z podatku gminnego stanowią średnio dwie trzecie ogółu dochodów z podatków lokalnych i są czterokrotnie wyższe od dochodów z podatku od nieruchomości. Blisko jedna piąta dochodów bieżących gmin pochodzi z powyższych podatków lokalnych.

W Niemczech samorządowy system podatkowy opiera się na podatkach dzielonych i podatkach własnych. Jak zaznaczono wcześniej, większość dochodów podatkowych krajów związkowych (landów) pochodzi z podatków dzielonych, głównie z: PIT, CIT i VAT. Ich podatki własne 
obejmują: podatek od spadków, podatek od środków transportu, podatek od zakupu nieruchomości, podatek od loterii i podatek od piwa, jednak autonomia samorządu regionalnego w tym wypadku jest niewielka, z wyjątkiem podatku od zakupu nieruchomości. Główne gminne podatki dzielone to PIT i podatek od odsetek oraz w ograniczonym zakresie VAT. Podatkami własnymi gmin w pierwszej kolejności są podatek lokalny od działalności gospodarczej oraz podatek od nieruchomości ${ }^{19}$.

Belgię wyróżnia otwarty system podatków lokalnych, a prawo do stanowienia podatków przez władze lokalne jest zapisane w przepisach konstytucyjnych. Władze lokalne są uprawnione do pobierania wszystkich podatków o znaczeniu lokalnym, zgodnie z zasadami określonymi w konstytucji. Dotyczy to m.in. podatków: od odpadów, od reklamy, od drugiego domu. Władze lokalne - choć mogą we wprowadzanych podatkach określać stawki podatkowe i podstawy wymiaru - nie mają jednak w tej dziedzinie nieograniczonej swobody, ponieważ art. 170 konstytucji zezwala ustawodawcy federalnemu na ograniczenie możliwości poboru podatków przez gminy ${ }^{20}$. Kluczową kwestią stają się zatem ustalenia dotyczące nadzorowania gmin i ograniczania ich uprawnień do nakładania i poboru podatków. To organy nadzorcze (tj. regiony) są odpowiedzialne za finansowanie, a nawet za organizację gmin, lecz w obecnych ramach ustawowych mają one jedynie niewielkie możliwości, aby bezpośrednio interweniować w kwestii podnoszenia podatków przez gminy ze względu na interes publiczny lub regionalny. W związku z tym regionalna interwencja w tym obszarze może nastąpić pośrednio i na zasadach wynegocjowanych w ramach „fiskalnych porozumień pokojowych"21. W gminach jednak największe znaczenie fiskalne mają dopłaty do podatków federalnych (podatku dochodowego od osób fizycznych) i podatków ustanowionych przez władze regionalne. W tym przypadku każda gmina może ustanowić stawki podatkowe, poza podatkiem od samochodów. Najistotniejszym źródłem dochodów podatkowych gmin belgijskich jest dodatek do regionalnego podatku od nieruchomości'22.

W Hiszpanii największą autonomię podatkową mają Kraj Basków i Nawarra, nie dotyczy to jednak ceł importowych, podatków od wynagrodzeń, podatku od towarów i usług oraz akcyzy. Inne wspólnoty autonomiczne korzystają z podatków dzielonych z rządem centralnym, w przypadku których mają pewną swobodę kształtowania elementów konstrukcyjnych opodatkowania. Otrzymują 33\% PIT, 35\% wpływów z VAT, 40\% akcyzy na tytoń, alkohol i benzynę oraz

19 OECD/UCLG, Subnational Governments Around the World. Structure and Finance, Barcelona 2016, https:// www.uclg.org/sites/default/files/global_observatory_on_local_finance_0.pdf [dostęp: 23 kwietnia 2021 r.], Part III, Country profiles, Germany.

20 Art. 170 par. 4 stanowi, że obciążenia i podatki mogą być ustanawiane przez aglomeracje, federacje gmin i przez gminy tylko na podstawie decyzji ich rad, jakkolwiek ustawa określa wyjątki od tej reguły.

21 H. Hammar, U. Wüthrich-Pelloli, Local and Regional Democracy in Belgium, Council of Europe, 27th Session, Strasbourg, 14-16 October 2014, CG(27)7FINAL, s. 31, https://rm.coe.int/168071a308\#_Toc391652445 [dostęp: 23 kwietnia 2021 r.].

22 J.F. Husson, C. Mahieu, C. Sägesser, Federalism and Decentralisation in Belgium [w:] The Palgrave Handbook of Decentralisation in Europe, red. J.M. Ruano, M. Profiroiu, Palgrave Macmillan, Cham 2017, https://orbi. uliege.be/bitstream/2268/193242/3/Husson\%20et\%20al\%20\%282016\%29\%20Decentralisation\%20in\%20 Belgium.pdf [dostęp: 22 kwietnia 2021 r.]. 
100\% wpływów z podatku od energii elektrycznej i niektórych środków transportu. Ponadto wspólnoty autonomiczne mają uprawnienia do czerpania wpływów z podatku majątkowego, podatku od spadków i darowizn oraz podatku z tytułu transferu kapitału, podatku od gier hazardowych, akcyzy na pojazdy i podatku od sprzedaży detalicznej węglowodorów²3. Gminom przysługują wpływy podatkowe z podatków dzielonych z rządem centralnym oraz z podatków własnych. Do podatków dzielonych należą: PIT, VAT i akcyza, jednakże gminy mogą partycypować w tych podatkach, pod warunkiem że są stolicą prowincji bądź wspólnoty autonomicznej lub liczebność ich populacji wynosi co najmniej 75 tys. mieszkańców. Hiszpańskie gminy nie mogą swobodnie tworzyć podatków. Parlament regionalny musi ustanowić podatki, natomiast gminy mogą zdecydować o ich nałożeniu i są całkowicie niezależne w ustalaniu takich aspektów podatkowych, jak: stawki, podstawy opodatkowania lub ulgi. Podatki gminne mogą mieć charakter obligatoryjny bądź fakultatywny. Obligatoryjne podatki własne gmin obejmują podatek od nieruchomości, podatek od środków transportu oraz lokalny podatek od działalności gospodarczej. Podatki fakultatywne zaś to podatek od transakcji dotyczących nieruchomości na obszarach miejskich oraz podatek od budynków, instalacji i robót. Prowincje mają prawo pobierać tylko dodatek do lokalnego podatku od działalności gospodarczej i są uprawnione do korzystania z niektórych wspólnych dochodów podatkowych (PIT, VAT i CIT) ${ }^{24}$.

W Portugalii oba regiony autonomiczne także cieszą się pewną autonomią podatkową, ponieważ są w stanie zatrzymać prawie wszystkie krajowe dochody podatkowe generowane na ich terytoriach (w tym PIT i CIT) oraz mogą tworzyć nowe podatki. Dochody podatkowe gmin pochodzą z podatków wspólnych (udział w PIT) oraz własnych. Własne podatki obejmują podatek od nieruchomości, podatek od transakcji dotyczących nieruchomości, gminny podatek od środków transportowych oraz gminny dodatek do $\mathrm{CIT}^{25}$.

Włochy wyróżnia z kolei to, że są państwem, w którym na źródło samorządowych dochodów podatkowych składają się aż cztery grupy podatków, przy tym żadna z form opodatkowania nie jest dominująca. Dochody włoskich samorządów są uzyskiwane zarówno z podatków dzielonych, jak i ze źródeł własnych. Podatki regionalne obejmują: podatek regionalny od działalności gospodarczej (IRAP), regionalny dodatek do podatku dochodowego od osób fizycznych, regionalny podatek samochodowy. Ponadto regiony mają udział w niektórych podatkach krajowych (PIT, CIT, opłata skarbowa, akcyza). Na prowincjonalne podatki własne składają się: podatek od ubezpieczenia samochodu, podatek od rejestracji pojazdu i udział w PIT. Gminy mają również prawo do dodatku do podatku dochodowego od osób fizycznych, ale większość dochodów podatkowych tych jednostek samorządu pochodzi z podatków własnych, w tym z gminnego podatku od nieruchomości i z gminnego podatku od pozwoleń na budynki. Od 2014 r. obowiązuje podatek komunalny, w ramach którego zintegrowano dotychczasowe opodatkowanie nieruchomości oraz opodatkowanie na rzecz sfinansowania gospodarki śmieciowej gmin i innych usług świadczonych przez gminy (m.in. oświetlenie publiczne, drogi).

23 OECD/UCLG, op. cit., Part III, Country profiles, Spain.

24 Local Public..., s. 195.

25 OECD/UCLG, op. cit., Part III, Country profiles, Portugal. 
We Francji większość dochodów podatkowych samorządu terytorialnego pochodzi z podatków własnych, chociaż rola podatków dzielonych wzrosła od czasu wprowadzenia przepisów dotyczących decentralizacji (w latach 2003-2004) oraz przepisów reformujących podatki lokalne (z 2010 r.). Na mocy tych uregulowań zniesiono lokalny podatek od przedsiębiorstw i znacząco zmieniono lokalny system podatkowy. Reforma zaowocowała również „specjalizacją" podatkową poszczególnych szczebli samorządu terytorialnego, a także zmniejszeniem uprawnień władz departamentalnych i regionalnych w zakresie opodatkowania. Gminne dochody z podatków obejmują: podatek od nieruchomości (od budynków i gruntów), podatek lokalny związany z miejscem zamieszkania ${ }^{26}$ oraz tzw. ekonomiczny wkład terytorialny (dalej: CET), który muszą wnosić przedsiębiorstwa i samozatrudnieni. CET składa się z dwóch komponentów: w przypadku pierwszego opodatkowaniu podlega roczna wartość najmu nieruchomości $(C F E)^{27}$, a drugiego - określony procent wartości dodanej przedsiębiorstwa (CVAE). Dochody departamentów obejmują: podatek od nieruchomości (od budynków), CVAE, podatek od spółek sieciowych (IFER ${ }^{28}$ ) oraz podatek od transakcji dotyczących nieruchomości. Na regionalne dochody podatkowe składają się CVAE i IFER. Regiony i departamenty wraz z rządem centralnym partycypują w podatkach pośrednich - regiony w podatku od zużycia produktów energetycznych, a departamenty w podatku od umów ubezpieczeniowych ${ }^{29}$.

Analizując strukturę dochodów podatkowych sektora samorządowego na tle wskaźników udziału samorządowych dochodów podatkowych w PKB oraz w dochodach podatkowych ogółem, można zauważyć pewną prawidłowość. Mianowicie dla tych państw, które charakteryzują się najniższymi wskaźnikami udziału w PKB i dochodach podatkowych ogółem, dominującym źródłem dochodów podatkowych jest opodatkowanie nieruchomości, te zaś państwa, w których te mierniki są najwyższe, gros wpływów osiągają z opodatkowania dochodów.

W podsumowaniu należy stwierdzić, że analizowane dane i informacje nie pozwalają na wyciągnięcie jednoznacznego wniosku, jaki jest obowiązujący model opodatkowania lokalnego w wybranych państwach europejskich. Nie można także ściśle ocenić, czy przyjęcie modelu licznych źródeł opodatkowania jest bardziej efektywne od stosowania modelu jednego dominującego źródła opodatkowania. Trudno jest też stwierdzić, który z tych modeli jest bardziej wydajny fiskalnie. Wysokość osiąganych przez samorządy terytorialne dochodów podatkowych jest bowiem uzależniona od wielu czynników - poczynając od uwarunkowań konstytucyjnych i ustawowych oraz woli przekazania przez władze centralne określonych podatków lub ich elementów konstrukcyjnych we władztwo samorządowe, a kończąc na zdolności władz lokalnych do sprawnego administrowania podatkami. Niemniej jednak to, że wyłącznie w Wielkiej Brytanii

26 Podatek od umeblowanego mieszkania płaci każda osoba, która 1 stycznia roku podatkowego ma do swojej dyspozycji podlegający opodatkowaniu lokal, niezależnie od statusu (właściciel, najemca, wolny lokator).

27 Podstawę opodatkowania stanowi wartość czynszowa ustalona według administracyjnej wyceny gruntów lub budynków, które podlegają opodatkowaniu podatkiem od nieruchomości lub podatkiem gruntowym i znajdują się we Francji.

28 IFER obejmuje dziewięć podatków specjalnych nakładanych na firmy zarządzające infrastrukturą sieciową (energia elektryczna, kolej itp.).

29 European Commission, op. cit. oraz OECD/UCLG, op. cit., Part III, Country profiles, France. 
obowiązuje tylko jedno źródło opodatkowania, wskazuje, iż do zapewnienia większej wydajności podatków samorządowych lepszy jest model oparty na wielu źródłach opodatkowania, gdyż pozwala on skorygować ewentualne wady jednego rodzaju opodatkowania. Mnogość źródeł opodatkowania sprawia także, że struktura podatków samorządowych jest bardziej elastyczna i władze samorządowe mają możliwość dostosowywania tych podatków do lokalnych warunków oraz okoliczności w granicach określonych przepisami prawa. Ponadto wiele źródeł opodatkowania oznacza większą elastyczność dochodową lokalnej bazy podatkowej, co może umożliwiać samorządom wpływanie na wydajność podatków samorządowych w zależności od fazy cyklu koniunkturalnego czy potrzeb finansowych związanych z realizowanymi zadaniami.

\section{Przegląd opodatkowania majątku}

W literaturze przedmiotu podkreśla się, że podatki majątkowe stanowią dla samorządu terytorialnego jedno z najlepszych źródeł dochodów podatkowych oraz zapewniają mu realną władzę podatkową. W przypadku tego rodzaju opodatkowania nie pojawiają się żadne istotne problemy wynikające z różnic w stawkach podatkowych i praktyki administracyjnej poszczególnych jednostek samorządu terytorialnego. Podstawa opodatkowania jest przeważnie nieruchoma. Problemy związane z oszustwami podatkowymi lub ucieczką przed opodatkowaniem także są nieliczne. Dochody z opodatkowania majątku okazują się w miarę stabilne i przewidywalne. Najistotniejszym mankamentem podatku od majątku jest trudność w ustaleniu podstawy opodatkowania ${ }^{30}$.

Generalnie wśród analizowanych państw europejskich nie ma takiego, w którym samorząd terytorialny nie uzyskiwałby wpływów budżetowych z podatków majątkowych. W większości państw obowiązuje nawet po kilka różnych podatków od majątku. Niemniej jednak jedynym bądź dominującym źródłem samorządowego opodatkowania majątku w większości państw europejskich są podatki związane z powtarzalnym opodatkowaniem nieruchomości. Wyjątek stanowią samorządy regionalne trzech państw federacyjnych (Belgii, Hiszpanii i Niemiec), gdzie największe wpływy z opodatkowania majątku pochodzą w pierwszej kolejności z opodatkowania transakcji finansowych i kapitałowych, a w drugiej - z opodatkowania spadków i darowizn.

Mimo tak powszechnego stosowania podatków majątkowych grupa państw, w której opodatkowanie majątku to najważniejsze źródło samorządowych dochodów podatkowych, jest w istocie niewielka. Jeśli uwzględnić również te przypadki, w których samorząd terytorialny jest w jakiejś formie beneficjentem podatku dochodowego od osób fizycznych - nawet wtedy, kiedy podatek ten jest pobierany przez państwo - to spośród podatków samorządowych opodatkowanie majątku w praktyce przynosi najwyższe wpływy w: Wielkiej Brytanii, Irlandii, Grecji i Holandii.

W Austrii opodatkowanie majątku stanowi podatek od nieruchomości. Stawka podatkowa jest ustanawiana w przepisach federalnych, gminy ustalają zaś wymiar mnożnika tej stawki. Zazwyczaj federalna stawka podatkowa wynosi 0,2\%, a gminny mnożnik stawki federalnej może osiągnąć nawet $500 \%{ }^{31}$.

30 M.F. Ambrosiano, M. Bordignon, op. cit., s. 326.

31 The European Tax Handbook, red. M. Alvarado et al., IBFD, Amsterdam 2019, s. 89. 
Tabela 2. Struktura dochodów podatkowych sektora samorządowego z opodatkowania majątku w 2018 r.

\begin{tabular}{|c|c|c|c|c|c|c|c|}
\hline & 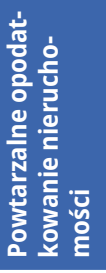 & 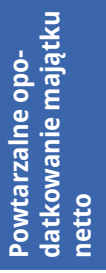 & 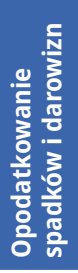 & 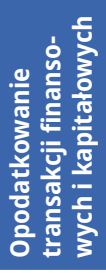 & 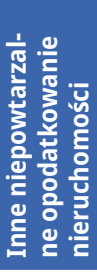 & 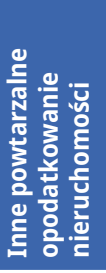 & 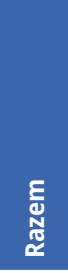 \\
\hline \multicolumn{8}{|l|}{ Austria } \\
\hline samorząd regionalny & 100,0 & 0,0 & 0,0 & 0,0 & 0,0 & 0,0 & 100,0 \\
\hline samorząd lokalny & 100,0 & 0,0 & 0,0 & 0,0 & 0,0 & 0,0 & 100,0 \\
\hline \multicolumn{8}{|l|}{ Belgia } \\
\hline samorząd regionalny & 4,5 & 0,0 & 41,1 & 54,4 & 0,0 & 0,0 & 100,0 \\
\hline samorząd lokalny & 100,0 & 0,0 & 0,0 & 0,0 & 0,0 & 0,0 & 100,0 \\
\hline Czechy & 100,0 & 0,0 & 0,0 & 0,0 & 0,0 & 0,0 & 100,0 \\
\hline Dania & 100,0 & 0,0 & 0,0 & 0,0 & 0,0 & 0,0 & 100,0 \\
\hline Estonia & 100,0 & 0,0 & 0,0 & 0,0 & 0,0 & 0,0 & 100,0 \\
\hline Finlandia & 100,0 & 0,0 & 0,0 & 0,0 & 0,0 & 0,0 & 100,0 \\
\hline Francja & 79,6 & 0,0 & 0,0 & 20,4 & 0,0 & 0,0 & 100,0 \\
\hline Grecja & 37,7 & 62,3 & 0,0 & 0,0 & 0,0 & 0,0 & 100,0 \\
\hline \multicolumn{8}{|l|}{ Hiszpania } \\
\hline samorząd regionalny & 0,3 & 9,0 & 19,0 & 71,7 & 0,0 & 0,0 & 100,0 \\
\hline samorząd lokalny & 76,9 & 5,7 & 0,8 & 1,2 & 15,4 & 0,0 & 100,0 \\
\hline Holandia & 100,0 & 0,0 & 0,0 & 0,0 & 0,0 & 0,0 & 100,0 \\
\hline Irlandia & 100,0 & 0,0 & 0,0 & 0,0 & 0,0 & 0,0 & 100,0 \\
\hline Litwa & 98,5 & 0,0 & 1,5 & 0,0 & 0,0 & 0,0 & 100,0 \\
\hline Łotwa & 100,0 & 0,0 & 0,0 & 0,0 & 0,0 & 0,0 & 100,0 \\
\hline \multicolumn{8}{|l|}{ Niemcy } \\
\hline samorząd regionalny & 0,0 & 0,0 & 32,6 & 67,4 & 0,0 & 0,0 & 100,0 \\
\hline samorząd lokalny & 100,0 & 0,0 & 0,0 & 0,0 & 0,0 & 0,0 & 100,0 \\
\hline Polska & 87,3 & 0,0 & 1,1 & 11,6 & 0,0 & 0,0 & 100,0 \\
\hline Portugalia & 60,4 & 0,0 & 0,0 & 39,6 & 0,0 & 0,0 & 100,0 \\
\hline Słowacja & 100,0 & 0,0 & 0,0 & 0,0 & 0,0 & 0,0 & 100,0 \\
\hline Słowenia & 81,1 & 0,0 & 3,6 & 14,5 & 0,7 & 0,0 & 100,0 \\
\hline Szwecja & 100,0 & 0,0 & 0,0 & 0,0 & 0,0 & 0,0 & 100,0 \\
\hline Węgry & 100,0 & 0,0 & 0,0 & 0,0 & 0,0 & 0,0 & 100,0 \\
\hline Włochy & 94,5 & 0,0 & 0,0 & 0,0 & 0,4 & 5,0 & 100,0 \\
\hline Wielka Brytania & 99,2 & 0,0 & 0,0 & 0,0 & 0,8 & 0,0 & 100,0 \\
\hline
\end{tabular}

Źródło: opracowanie własne na podstawie OECD, op. cit. 
W Belgii w zakresie opodatkowania majątku należy zwrócić uwagę na podatek spadkowy, podatek od przeniesienia prawa własności na wypadek śmierci oraz podatek od dochodu katastralnego. Władztwo podatkowe nad podatkiem spadkowym i podatkiem od przeniesienia prawa własności na wypadek śmierci mają regiony - mogą one odpowiadać za określenie takich elementów konstrukcyjnych tych podatków, jak: stawki podatkowe, podstawa opodatkowania i ulgi podatkowe. Elementy te są zróżnicowane w zależności od regionu. Wprawdzie rozróżnia się podatek spadkowy i podatek od przeniesienia prawa własności na wypadek śmierci, ale stawki obu należności są podobne w poszczególnych regionach ${ }^{32}$. Podatek od dochodu katastralnego jest dochodem władz samorządowych różnego szczebla. Stawki podatkowe, podstawa opodatkowania i ulgi podatkowe są ustanawiane przez władze regionalne, dlatego elementy te różnią się w zależności od regionu. W Regionie Flamandzkim stawka wynosi 3,97\%, podczas gdy w Regionie Walońskim i Regionie Stołecznym Brukseli - 1,25\%. Dodatki do podatku od dochodu katastralnego stanowione przez prowincje i gminy mogą podnieść efektywną stawkę podatku od dochodu katastralnego o 25-60\% lub więcej ${ }^{33}$. Podstawę opodatkowania tym podatkiem stanowi dochód katastralny, tj. dochód, który przypuszczalnie uzyskałby właściciel z wynajmu danej nieruchomości w określonym czasie. Chociaż władze regionalne mogą same określić podstawę opodatkowania, to nadal wykorzystują dochód katastralny ustalony przez federalną administrację katastralną, która posiada wyłączne kompetencje w zakresie określania dochodu katastralnego. Ten dochód wciąż odnosi się do domniemanego dochodu z najmu z 1975 r. i podlega indeksacji. W roku podatkowym 2020 współczynnik korekty inflacji wynosił $1,8492^{34}$.

W Czechach autonomia podatkowa gmin jest raczej nieduża - można ją zauważyć jedynie w odniesieniu do podatku od nieruchomości, gdyż gminy mają swobodę ustalania lokalnej stawki tego podatku na ich terytorium.

W Danii jako podatek majątkowy funkcjonuje podatek gruntowy, w odniesieniu do którego gminy mają prawo do ustalania stawek w określonych granicach (od 16\% do 34\%0 ${ }^{35}$ ).

W Estonii gminy czerpią dochód z podatku gruntowego, który jest wprawdzie podatkiem o charakterze krajowym, ale wpływy z niego w całości trafiają do budżetów gmin. Ponadto to władze lokalne określają stawkę podatkową w granicach ustawowych 0,1-2,5\% i mają prawo do zwolnienia niektórych podatników z opodatkowania ${ }^{36}$. Wyraźną wadą tego podatku jest to, że opiera się na przestarzałej wycenie gruntów podlegających opodatkowaniu.

W Finlandii na samorządowe opodatkowanie majątku składa się pięć podatków: ogólny podatek od nieruchomości, podatek od trwałej zabudowy mieszkalnej, podatek od innego rodzaju zabudowy mieszkalnej, podatek od elektrowni oraz podatek od elektrowni jądrowych. Władze gminne mają swobodę określania stawek opodatkowania majątku w ramach dolnych

32 European Commission, op. cit.

33 The European..., s. 186.

34 European Commission, op. cit.

35 Ibidem.

36 Rahandusministeerium, Personal Income Tax, https://www.rahandusministeerium.ee/en/tax-and-customs-policy/taxes [dostęp: 23 kwietnia 2021 r.]. 
i górnych limitów ustalonych przez rząd centralny. Średnie stawki opodatkowania majątku rosły z biegiem czasu, jednak nie w takim tempie jak stawki podatku dochodowego od osób fizycznych. W związku z tym, że wysokie podatki od nieruchomości mogą odstraszyć inwestorów, gminy raczej powstrzymują się od intensywniejszego wykorzystywania tej daniny ${ }^{37}$.

We Francji finansowanie lokalnych samorządów jest oparte na podatku od nieruchomości gruntowej (taxe foncière), który opłaca właściciel gruntu, oraz na podatku mieszkaniowym (taxe d'habitation) opłacanym przez zamieszkującego dom czy mieszkanie. Jeżeli właściciel nieruchomości mieszka w swoim domu, wówczas płaci oba podatki. Poborcą tych podatków jest wprawdzie państwo, lecz pozyskiwane kwoty są kierowane do władz lokalnych. Władze te mają prawo do ustalania taryf, których górny pułap jest ustawowo ograniczany. Zauważa się duże zróżnicowanie kwot obu płaconych podatków w zależności od regionu i szacunkowej wartości nieruchomości. Na początku każdego roku państwo przekazuje samorządom informację o maksymalnych taryfach podatków katastralnych, a samorządy uchwalają własne stawki nieprzekraczające propozycji rządowych ${ }^{38}$.

Do greckiego samorządu terytorialnego wpływają corocznie dochody z lokalnego podatku od nieruchomości. Stawka tego podatku jest ustalana przez władze lokalne i waha się od 0,025\% do 0,035\% wartości nieruchomości ${ }^{39}$.

W Hiszpanii to w kompetencjach gmin leży ustanawianie podatku od nieruchomości. Stawka podatku wynosi 0,4\% w przypadku własności miejskiej i 0,3\% w przypadku własności wiejskiej, ale gminy mogą podwyższyć lub obniżyć te stawki w granicach określonych w ustawie i zgodnie z okolicznościami w niej wyszczególnionymi ${ }^{40}$. Gminy mają także prawo do nakładania podatku od wzrostu wartości terenów miejskich. Opodatkowaniu podlega wzrost wartości gruntów z upływem czasu, przy okazji przeniesienia prawa własności w dowolny sposób bądź powstania lub przekazania praw majątkowych ograniczających prawa własności. Podstawę opodatkowania ustala organ centralny, natomiast uprawnienia do określenia stawek i ulg podatkowych posiada także gmina. Maksymalna stawka podatku, jaka może być zastosowana w przypadku podatku od wzrostu wartości gruntu miejskiego, może wynieść 30\% ${ }^{41}$. Z kolei w kompetencjach wspólnot autonomicznych leży ustanawianie podatku od spadków i darowizn. Wspólnoty autonomiczne mają prawo do określania własnych stawek podatkowych tylko w określonych granicach. Jeśli stawki regionalne nie zostaną ustalone na czas, to mają zastosowanie przepisy ogólne i tabela opodatkowania z nich wynikająca ${ }^{42}$.

W Irlandii samorządowy podatek od nieruchomości jest nakładany na nieruchomości komercyjne. W lipcu 2019 r. regulacje normujące jego funkcjonowanie zostały zmienione także pod względem uprawnień władz lokalnych, jednak część przepisów będzie dopiero wdrażana. W celu zwiększenia niezależności finansowej samorządów wyposażono je w nowe

37 Local Public..., s. 84.

38 K.A. Kopyściańska, op. cit., s. 384-385.

39 The European..., s. 464.

40 European Commission, op. cit.

41 Ibidem.

42 The European..., s. 1082-1083. 
uprawnienia do określania lokalnych stawek podatku od nieruchomości. Ponadto w kontekście kryzysu finansowego z 2013 r. do porządku prawnego zostało ponownie wprowadzone opodatkowanie nieruchomości mieszkalnych - kwotę podatku oblicza się na podstawie wartości rynkowej nieruchomości mieszkalnej na dzień wyceny. Elementy konstrukcyjne tego opodatkowania są ustanawiane przez władze centralne, jakkolwiek od 1 stycznia 2015 r. władze lokalne mogą według własnego uznania zmieniać stawki o $\pm 15 \%$. Wiele samorządów skorzystało z tej możliwości ${ }^{43}$.

W Holandii duża część samorządowych wpływów podatkowych pochodzi z podatku od nieruchomości, który jest płacony przez właścicieli i użytkowników nieruchomości mieszkalnych oraz niemieszkalnych. Gminy mają uprawnienia do ustalania stawek tego podatku, ale tylko w granicach określonych przez organ centralny. Z kolei podstawę opodatkowania ustala organ centralny, ale wartość, która jest podstawą, corocznie aktualizują władze lokalne. W zakresie ulg istnieją zarówno ulgi ustawowe, jak i ulgi udzielane indywidualnie przez władze lokalne ${ }^{44}$.

Na Litwie samorządowe dochody podatkowe związane z opodatkowaniem majątku obejmują podatek od nieruchomości i podatek gruntowy, w przypadku którego przedmiotem opodatkowania są grunty prywatne. Gminy mają możliwość ustalania stawek podatku od nieruchomości oraz podatku od gruntu (od 2013 r.) w granicach określonych prawem (lub decyzjami władz centralnych $)^{45}$.

Na Łotwie podatek od nieruchomości (od gruntów i budynków) jest podatkiem dzielonym. Władze lokalne nie mogą określać własnych stawek podatkowych, gdyż te są ustalane przez władze centralne, przy czym od 2013 r. władze lokalne mają większą autonomię w zakresie korekty stawek podatku od nieruchomości (w ramach z góry określonego przedziału 0,2-3\%)

W Niemczech dochody z podatku od nieruchomości trafiają wyłącznie do budżetów gmin, jednak wyliczenie wysokości tego podatku wymaga przeprowadzenia dwóch operacji. W pierwszej urząd skarbowy ustala podatek podstawowy i przekazuje tę informację gminie. W drugiej to gmina stosuje do podatku podstawowego mnożnik ustalony przez radę gminy i określa ostateczną kwotę podatku. Ponieważ gminy mogą ustalać mnożnik według własnego uznania, obciążenie podatkowe może się różnić w zależności od gminy. W 2018 r. średni mnożnik gminny wyniósł 339\% w przypadku podatku od nieruchomości klasy A (gospodarstwa rolne i leśne) oraz $472 \%$ w przypadku podatku od nieruchomości klasy B (inne nieruchomości) ${ }^{47}$. Z kolei kraje związkowe uzyskują wpływy z podatku od zakupu nieruchomości oraz z podatku od spadków i darowizn. Jeśli chodzi o podatek od zakupu nieruchomości, to podstawowa stawka podatku wynosi 3,5\%, lecz od 1 stycznia 2007 r. niemieckie kraje związkowe mają prawo do samodzielnego ustalania stawki. Obecnie wysokość stawek podatkowych waha się od 3,5\% do 6,5\% ${ }^{48}$. Jeśli chodzi o dochody z podatku od spadków i darowizn, to przypadają one krajom związko-

\footnotetext{
43 European Commission, op. cit.

44 Ibidem.

45 OECD/UCLG, op. cit., Part III, Country profiles, Lithuania.

46 Ibidem, Part III, Country profiles, Latvia.

47 European Commission, op. cit.

48 Ibidem.
} 
wym, ale wszystkie elementy konstrukcji tego opodatkowania (stawki podatkowe, podstawę opodatkowania oraz ulgi podatkowe) określa rząd federalny ${ }^{49}$.

W Portugalii podatek od nieruchomości jest corocznie nakładany na grunty lub budynki przez gminy, które mają swobodę ustalania stawki w przedziale 0,3-0,8\% wartości nieruchomości wiejskiej lub miejskiej podlegającej opodatkowaniu. Oczekuje się, że dochody z podatku od nieruchomości wzrosną w najbliższej przyszłości dzięki przeszacowaniu 4,9 mln nieruchomości.

Na Węgrzech podatek od nieruchomości stanowi drugie pod względem ważności źródło samorządowych dochodów podatkowych. Jest on opłacany przez właścicieli i obliczany na podstawie powierzchni lub powierzchni użytkowej bądź skorygowanej wartości rynkowej. Władze lokalne decydują o wprowadzeniu podatku od nieruchomości na obszarze danej gminy. Zgodnie z regulacjami ustawowymi to samorząd może swobodnie określać stawkę podatku w granicach maksymalnej stawki ustawowej i inne kryteria (w obszarze podstawy opodatkowania oraz ulg) w zakresie dopuszczonym przepisami prawa ${ }^{50}$.

W Słowacji jednym z siedmiu podatków, które mogą być nakładane przez gminy, jest podatek od nieruchomości. Władze lokalne ustalają także stawki tych podatków i mają dużą autonomię w zakresie ich podstawy opodatkowania (zwolnienia, obniżki stawek) ${ }^{51}$. W przepisach ustawowych wprawdzie określono stawki tych podatków, ale jednocześnie dopuszczono możliwość ustalenia przez organ administrujący podatkiem stawek niższych lub wyższych oraz wyznaczono granice dopuszczalnej maksymalnej wysokości tych stawek ${ }^{52}$.

W gminach słoweńskich własne opodatkowanie majątku obejmuje: podatek od nieruchomości, podatek od spadków i darowizn oraz podatek od obrotu nieruchomościami. Na władzach centralnych ciąży obowiązek ustanowienia wszystkich tych danin, tym samym gminy nie mają prawa do określania stawek tych podatków, podstawy opodatkowania ani ulg. Wyjątek stanowi jedynie opodatkowanie nieruchomości, w przypadku którego gminy mogą decydować o stawce podatkowej ${ }^{53}$.

W podsumowaniu należy stwierdzić, że opodatkowanie majątku jest źródłem samorządowych dochodów podatkowych we wszystkich analizowanych państwach, podatki majątkowe mają więc nadal istotne znaczenie fiskalne dla samorządów terytorialnych. Jednocześnie w większości państw opodatkowanie majątku nie stanowi dominanty w samorządowych dochodach podatkowych. Oznacza to, że obecnie podatki majątkowe nie przynoszą wystarczająco dużych wpływów, żeby zaspokoić potrzeby finansowe samorządów terytorialnych. Wymagają zatem dopełnienia przez opodatkowanie innych źródeł. Głównym walorem podatków majątkowych pozostaje natomiast stabilność, gdyż dzięki brakowi elastyczności dochody z opodatkowania majątku nie podlegają znacznym fluktuacjom w czasach spowolnienia lub wzrostu gospodarczego.

\footnotetext{
49 Ibidem.

50 Ibidem.

51 OECD/UCLG, op. cit., Part III, Country profiles, Slovak Republic.

52 Act No. 582/2004 Coll. on Local Taxes and Local Fee for Municipal Waste and Minor Construction Waste, as amended, https://www.mfsr.sk/en/taxes-customs-accounting/direct-taxes/local-taxes/local-taxes-local-fee-municipal-waste-minor-construction-waste-act-582/2004-coll/ [dostęp: 23 kwietnia 2021 r.].

53 Local Public..., s. 183.
} 


\section{Przegląd opodatkowania dochodów, zysków i zysków kapitałowych}

Opodatkowanie dochodów zasadniczo należy do kompetencji władz centralnych ze względu na funkcje redystrybucyjną i stabilizacyjną podatków dochodowych. Samorząd terytorialny często ma jednak dostęp do zasobów finansowych pochodzących z tych podatków w postaci albo udziału w tych wpływach, albo możliwości nakładania samorządowego dodatku do podatku ogólnokrajowego. Jak zauważa się w piśmiennictwie, samorządowy dodatek do opodatkowania dochodów osobistych może być doskonałym instrumentem umożliwiającym samorządowi terytorialnemu rozwój bądź większą samodzielność finansową ${ }^{54}$.

Nie we wszystkich analizowanych państwach samorząd terytorialny dysponuje dochodami podatkowymi z opodatkowania dochodów, zysków i zysków kapitałowych. Nie korzystają z nich: Czechy, Estonia, Grecja, Holandia, Irlandia, Litwa, Słowacja i Wielka Brytania, a w przypadku Austrii wpływów z opodatkowania dochodów nie czerpie tylko samorząd lokalny. Niemniej jednak w części tych państw wpływy z podatków dochodowych, w szczególności z podatku dochodowego od osób fizycznych, stanowią podstawę transferów finansowych z budżetu centralnego do budżetów samorządowych. Należy także zauważyć, że wprawdzie Francja i Węgry w 2018 r. uzyskały dochody podatkowe z opodatkowania dochodów, ale ich kwota była na tyle nieduża, iż udział tych wpływów w samorządowych dochodach podatkowych był zbliżony do $0 \%$.

Spośród państw, w których samorząd terytorialny partycypuje we wpływach z opodatkowania dochodów, zysków i zysków kapitałowych, tylko w Belgii, Danii, na Łotwie, w Słowenii, Szwecji i we Włoszech wyłącznym źródłem tych wpływów jest opodatkowanie dochodów osób fizycznych. W pozostałych państwach samorząd terytorialny uzyskuje dochody podatkowe z opodatkowania dochodów zarówno osób fizycznych, jak i osób prawnych, niemniej fiskalne znaczenie wpływów z opodatkowania tych ostatnich jest znacznie mniejsze. Można to powiązać z wyrażaną także w piśmiennictwie opinią, że opodatkowanie dochodów osób prawnych nie stanowi stabilnego źródła wpływów budżetowych, ponieważ jest silnie uzależnione od cyklów koniunktury gospodarczej ${ }^{55}$.

Ze względu na formę lokalnego opodatkowania dochodów analizowane państwa można podzielić na dwie grupy. Do pierwszej należy zaliczyć te państwa, w których władze samorządu terytorialnego mogą ustanawiać samorządowy dodatek do opodatkowania dochodów (m.in. Belgia, Dania, Finlandia, Szwecja), do drugiej zaś te, w których samorząd terytorialny ma udział we wpływach z opodatkowania dochodów i udział ten jest traktowany jako dochód własny (np. Łotwa, Słowenia, Niemcy).

Najlepszymi przykładami samorządowego opodatkowania dochodów osobistych są te państwa, które wyróżnia najwyższa fiskalna samodzielność mierzona udziałem samorządowych dochodów podatkowych w PKB i w dochodach podatkowych ogółem, a więc państwa skandynawskie: Szwecja, Dania i Finlandia.

54 R.M. Bird, R. Bahl, op. cit., s. 23.

55 M.F. Ambrosiano, M. Bordignon, op. cit., s. 327. 
Tabela 3. Struktura dochodów podatkowych sektora samorządowego z opodatkowania dochodów, zysków i zysków kapitałowych w 2018 r.

\begin{tabular}{|c|c|c|c|}
\hline & $\begin{array}{c}\text { Z opodatkowania osób } \\
\text { fizycznych }\end{array}$ & $\begin{array}{c}\text { Z opodatkowania osób } \\
\text { prawnych }\end{array}$ & Razem \\
\hline \multicolumn{4}{|l|}{ Austria } \\
\hline samorząd regionalny & 87,1 & 12,9 & 100,0 \\
\hline samorząd lokalny & \multicolumn{3}{|c|}{ nd. } \\
\hline \multicolumn{4}{|l|}{ Belgia } \\
\hline samorząd regionalny & 100,0 & 0,0 & 100,0 \\
\hline samorząd lokalny & 100,0 & 0,0 & 100,0 \\
\hline Czechy & \multicolumn{3}{|c|}{ nd. } \\
\hline Dania & 100,0 & 0,0 & 100,0 \\
\hline Estonia & \multicolumn{3}{|c|}{ nd. } \\
\hline Finlandia & 91,0 & 9,0 & 100,0 \\
\hline Francja & 50,0 & 50,0 & 100,0 \\
\hline Grecja & \multicolumn{3}{|c|}{ nd. } \\
\hline \multicolumn{4}{|l|}{ Hiszpania } \\
\hline samorząd regionalny & 99,4 & 0,6 & 100,0 \\
\hline samorząd lokalny & 78,3 & 21,7 & 100,0 \\
\hline Holandia & \multicolumn{3}{|c|}{ nd. } \\
\hline Irlandia & \multicolumn{3}{|c|}{ nd. } \\
\hline Litwa & \multicolumn{3}{|c|}{ nd. } \\
\hline Łotwa & 100,0 & 0,0 & 100,0 \\
\hline \multicolumn{4}{|l|}{ Niemcy } \\
\hline samorząd regionalny & 86,2 & 13,8 & 100,0 \\
\hline samorząd lokalny & 68,1 & 31,9 & 100,0 \\
\hline Polska & 84,2 & 15,8 & 100,0 \\
\hline Portugalia & 63,4 & 36,7 & 100,0 \\
\hline Słowacja & \multicolumn{3}{|c|}{ nd. } \\
\hline Słowenia & 100,0 & 0,0 & 100,0 \\
\hline Szwecja & 100,0 & 0,0 & 100,0 \\
\hline Węgry & 100,0 & 0,0 & 100,0 \\
\hline Włochy & 100,0 & 0,0 & 100,0 \\
\hline Wielka Brytania & \multicolumn{3}{|c|}{ nd. } \\
\hline
\end{tabular}

Źródło: opracowanie własne na podstawie OECD, op. cit.

W Szwecji gminnym podatkiem dochodowym od osób fizycznych opodatkowane są dochody z pracy zarobkowej (z zatrudnienia i działalności gospodarczej). Dochody z zysków nie podlegają temu podatkowi. Ze względu na to, że gminny podatek dochodowy od osób fizycznych nie może być odliczony przy ustalaniu kwoty państwowego podatku dochodowego od osób fizycznych, w praktyce podatek gminny jest dodatkiem do podatku państwowego. Gminny 
podatek dochodowy od osób fizycznych jest nakładany według stawki liniowej, którą ustanawia każda gmina. W 2019 r. średnia stawka gminnego podatku dochodowego od osób fizycznych wynosiła 32,19\%, w Sztokholmie mniej - 29,89\% ${ }^{56}$.

Duńskie gminy chętnie korzystają z prawa do ustalania stawek podatku dochodowego. $\mathrm{Na}$ przestrzeni kilkudziesięciu lat generowały wyższe dochody w celu zwiększania swoich wydatków. Średnio stawki podatkowe w gminnym podatku dochodowym od osób fizycznych wzrosły z ok. 15\% w 1976 r. do ok. 25\% w 2013 r. Chociaż częściowo taki wzrost był spowodowany decyzjami podjętymi na szczeblu krajowym, to budził on niepokój władz centralnych ze względu na jego konsekwencje makroekonomiczne. Wprawdzie już w 1979 r. ustanowiono instytucjonalną współpracę budżetową pomiędzy rządem centralnym a stowarzyszeniem samorządów lokalnych, której celem było dokonywanie uzgodnień dotyczących m.in. stawek podatków lokalnych, jednak efekty tej współpracy były niezadowalające. Mianowicie porozumienia między rządem centralnym i stowarzyszeniem samorządów były konsekwentnie łamane. Okres dobrego stanu finansów publicznych nie sprzyjał ewentualnym zmianom w tej dziedzinie, gdyż zarówno obywatele, jak i politycy opowiadali się za usługami publicznymi na najwyższym poziomie, a to pociągało za sobą wysokie wydatki przy wysokich stawkach podatkowych. Aby rozwiązać problem ciągłego wzrostu podatków, władze centralne przy okazji reformy samorządowej z 2007 r. wprowadziły nowy warunek. Sprowadza się on do tego, że wzrost ogólnej stawki gminnego podatku dochodowego został ograniczony - jeśli pewien samorząd lokalny musi podnieść swoją stawkę podatkową, to inny musi swoją stawkę obniżyć. Ta nowa zasada oraz klimat polityczny związany z kryzysem finansowym spowodowały, że stawki gminnego podatku dochodowego utrzymują się na względnie stałym poziomie, a różnice w opodatkowaniu w poszczególnych gminach się zmniejszają ${ }^{57}$. Na utrzymywanie się tego trendu wskazują również dane z ostatnich lat - średnia stawka gminnego podatku dochodowego wyniosła w 2020 r. 24,954\% wobec 24,926\% w 2019 r., przy tym w poszczególnych gminach stawka tego podatku kształtowała się w przedziale $22,8-27,8 \%$ w $2020 r^{58}$

W Finlandii, podobnie jak w Danii, najważniejszym podatkiem lokalnym jest gminny podatek dochodowy od osób fizycznych. Co do zasady stawka podatku jest liniowa, lecz ze względu na regulacje ustanowione na szczeblu centralnym w zakresie ulg podatkowych dla osób o niskich dochodach w praktyce ma on bardziej charakter progresywny. Władze lokalne mają uprawnienia do niemal swobodnego określania stawki podatkowej, natomiast władze centralne ustalają podstawę opodatkowania w gminnym podatku dochodowym od osób fizycznych ${ }^{59}$. W 2020 r. stawka gminnego podatku dochodowego od osób fizycznych wahała się od $17 \%$ do 23,5\% w zależności od gminy, a średnia ważona wyniosła 19,88\% ${ }^{60}$. Od 1993 r. gminom przydzielono część wpływów z podatku dochodowego od osób prawnych. Poziom przekazywanych wpływów był od tego czasu kilkukrotnie zmieniany. Po poważnych redukcjach w latach 1995-2003 udział

56 The European..., s. 1108-1109.

57 Local Public..., s. 53.

58 European Commission, op. cit.

59 Local Public..., s. 83.

60 European Commission, op. cit. 
gmin w podatku dochodowym od osób prawnych wzrósł ponownie w 2005 r. (jako rekompensata za ogólne obniżenie stawki podatkowej) oraz w 2009 r. (w ramach pakietu bodźców fiskalnych rządu centralnego $)^{61}$. W 2020 r. do gmin trafiło 32,13\% podatku dochodowego od osób prawnych ${ }^{62}$.

W Belgii regiony mogą pobierać regionalny dodatek do podatku dochodowego od osób fizycznych. Szósta reforma państwowa wprowadziła zasadniczą zmianę polegającą na ustanowieniu dopłaty regionalnej do federalnego podatku dochodowego od osób fizycznych. Regiony są uprawnione do modyfikowania stawek oraz określonych preferencji podatkowych, co może prowadzić do wzrostu stawki podatkowej. Stąd jednocześnie wprowadzono rozwiązania w celu zapobieżenia konkurencji fiskalnej. Mianowicie dochody regionów uzależniono od ich bazy podatkowej w podatku dochodowym od osób fizycznych. Innym ważnym źródłem dochodów podatkowych regionów są dawne podatki federalne, które zostały przeniesione właśnie do regionów, w tym: podatek od nieruchomości, opłaty rejestracyjne, podatek od spadków, podatek od darowizn, podatek od samochodów itp.

Jak już wspomniano, w ramach szóstej reformy państwowej regiony (Region Flamandzki, Region Waloński i Region Stołeczny Brukseli) uzyskały większą autonomię podatkową i mogą pobierać regionalny dodatek do podatku dochodowego od osób fizycznych. Ten element podatkowy wszedł w życie 1 lipca 2014 r. i obowiązuje od roku podatkowego 2015. Dzięki temu od 1 lipca 2014 r. każdy z tych regionów może ustalać zasady regionalnego dodatku do podatku dochodowego od osób fizycznych. Podstawę ustalenia regionalnego dodatku do PIT stanowi obniżona kwota podatku federalnego. Aby ją wyliczyć, odejmuje się od kwoty podatku federalnego kwotę, która równa się podatkowi federalnemu przeliczonemu z zastosowaniem właściwego współczynnika. W latach 2014-2016 współczynnik ten wynosił 25,990\%, a od roku dochodowego 2017 - 24,957\%. Stawka regionalnego dodatku do PIT w latach 2014-2016 kształtowała się na poziomie 35,117\%, chyba że region ustalił inną. Od 2017 r. stawka dodatku do PIT w regionie stołecznym wynosi 32,591\%. Stawki regionalnego dodatku do PIT mogą być różnicowane w zależności od przedziału podatkowego, z wyjątkiem dochodów podlegających odrębnemu opodatkowaniu - w tym przypadku stawki regionalnego dodatku muszą być liniowe. Regionalne ulgi podatkowe są powiązane z kompetencjami regionów ${ }^{63}$.

Prawo do ustanowienia dodatku do federalnego PIT mają także gminy. Każda z nich ustala własną stawkę dodatku do federalnego PIT, przy tym gminny dodatek nie ma zastosowania do opodatkowania odsetek i dywidend, jeśli nie mają one charakteru zawodowego ${ }^{64}$.

We Włoszech gminy mają prawo do wprowadzania gminnego dodatku do PIT od 1999 r. W ramach tego uprawnienia każda gmina może zdecydować się na nałożenie dodatku do PIT, jako uzupełnienie podatku nakładanego przez rząd centralny i regionalnego dodatku do PIT, w wyznaczonych granicach. Stawka gminnego dodatku do PIT jest ustalana corocznie przez burmistrza i zatwierdzana przez radę gminy na koniec każdego roku. Zależy ona od dochodu

61 Local Public..., s. 83.

62 European Commission, op. cit.

63 Ibidem.

64 Ibidem. 
podlegającego opodatkowaniu ustalonego zgodnie z prawem krajowym i ma taką samą podstawę opodatkowania jak krajowy PIT. Przy nakładaniu gminnego dodatku do PIT bierze się pod uwagę miejsce zamieszkania podatnika w danym roku podatkowym, a nie to, gdzie pracuje. Liczba gmin, które ustaliły własny dodatek do PIT, w miarę upływu czasu rosła: podczas gdy w 2001 r. ok. 4,8 tys. gmin (z 7960) charakteryzowało się brakiem stawki zerowej w przypadku dodatku do PIT, w 2015 r. już prawie 90\% gmin ustaliło własną stawkę tego dodatku. Te same zasady dotyczą regionalnego dodatku do PIT. Pozwalają one każdemu regionowi pobierać dodatek do PIT (liniowy lub progresywny) w zakresie określonym w prawie krajowym. Od 2007 r. gminy mogą także wprowadzić w ramach gminnego dodatku do PIT próg zwolnienia uzależniony od określonych wymogów dochodowych. Kolejna zmiana w ustalaniu dodatku gminnego do PIT (z 2011 r.) dała gminom możliwość przejścia ze stawki liniowej na system stawek progresywnych, przy czym stawki te muszą odnosić się do tych samych przedziałów, które są ustanowione w krajowym podatku dochodowym od osób fizycznych, i rosnąć wraz z dochodem. Od 2011 r. liczba gmin z progresywną skalą gminnego dodatku do PIT zwiększa się; w 2015 r. ponad jedna trzecia gmin ustanowiła taką skalę ${ }^{65}$.

Na Łotwie udziały w PIT ujmuje się w budżetach samorządowych i w budżecie państwa według następującego podziału: $80 \%$ to udziały budżetu jednostki samorządu terytorialnego właściwej dla miejsca zamieszkania płatnika, 20\% - udziały budżetu państwa ${ }^{66}$.

W Portugalii gminy otrzymują część PIT, która nie przekracza 5\% wpływów podatkowych pobieranych od mieszkańców (gminy mogą zdecydować o obniżeniu tego odsetka). Gminny dodatek do CIT obowiązuje w wysokości do 1,5\% dochodu podlegającego opodatkowaniu.

W Słowenii do reformy z 2007 r. udział gmin w PIT wynosił 35\% łącznych wpływów z tego podatku. Obecnie udział lokalny w PIT to 54\%, przy tym podział odbywa się według ustalonego klucza - 70\% kwoty stanowi tzw. udział obowiązkowy, a 30\% jest przeznaczone na rekompensatę solidarnościową. Wraz z reformą wzmocniono pionowe wyrównywanie podatków. Rozdysponowanie udziału obowiązkowego jest powiązane z bieżącymi potrzebami wydatkowymi gmin (bez inwestycji) i przybiera formę wymaganej kwoty na mieszkańca, która określa poziom finansowania statutowych zadań gmin wyliczany na podstawie kryteriów demograficznych i rozwojowych. Każdego roku rząd centralny negocjuje z gminami kwotę per capita. Kiedy wspomniane 70\% (z 54\% podatku dochodowego) jest niższe niż ustalona kwota, gminy otrzymują różnicę z rekompensaty solidarnościowej. Jeżeli 70\% przewyższa ustaloną kwotę lub jest jej równe, wówczas gminy nie otrzymują żadnego dodatkowego finansowania z rekompensaty solidarnościowej ${ }^{67}$. W sprzyjających warunkach ekonomicznych, kiedy większość gmin jest w stanie zaspokoić swoje potrzeby finansowe z dochodów własnych, część środków z rekompensaty solidarnościowej może pozostać w budżecie państwa.

65 E. Rubolino, The Efficiency and Distributive Effects of Local Taxes. Evidence from Italian Municipalities, Institute for Social and Economic Research, University of Essex, Essex 2019, s. 5.

66 European Commission, op. cit.

67 Zob. H.B. Johansen, G. Doganoglu, Local Democracy in Slovenia, Council of Europe, 35th Session, Strasbourg, 6-8 November 2014, CPL35(2018)03final, s. 24, https://www.coe.int/en/web/congress/35th-session-documents [dostęp: 23 kwietnia 2021 r.]. 
W Niemczech poza udziałami w podatkach dochodowych PIT i CIT samorząd terytorialny uzyskuje znaczące dochody podatkowe także z lokalnego podatku od działalności gospodarczej. Podatek ten dotyczy przedsiębiorców i zależy od ich realnych możliwości zarobkowania. Podstawą wymiaru jest zysk przedsiębiorstwa w rozumieniu przepisów o podatkach dochodowych. Ustalony w ten sposób zysk podlega stosownej modyfikacji, która ma na celu uwzględnienie charakteru podatku od działalności gospodarczej lub służy zapobieganiu podwójnemu opodatkowaniu. Podatek od działalności gospodarczej jest nakładany przez gminy i w każdej z nich może być inny. Efektywna stawka tego podatku zależy od stawki federalnej oraz jej wielokrotności zastosowanej przez władze gminne. Aby określić kwotę podatku od działalności gospodarczej, w pierwszej kolejności wylicza się podstawową kwotę podatku z użyciem stawki federalnej w wysokości 3,5\%, a następnie tę podstawową kwotę przelicza się współczynnikiem wielokrotności ustalonym przez władze gminne. Jego wartość zależy od potrzeb finansowych gminy. Współczynnik wielokrotności zasadniczo wynosi 200\%, chyba że władze gminne ustanowią ją na wyższym poziomie. Przykładowo w Berlinie wielokrotność ma wartość 410\%, we Frankfurcie nad Menem jest to 470\%, a w Hamburgu i Monachium - 490\% ${ }^{68}$.

W podsumowaniu należy stwierdzić, że w wielu państwach najwydajniejszym źródłem samorządowych dochodów podatkowych jest opodatkowanie dochodów, choć nie zawsze jest to związane z funkcjonowaniem samorządowego podatku dochodowego. Jednak nawet gdy taka forma opodatkowania istnieje, w praktyce w większości państw władze samorządowe mają ograniczone możliwości wpływu na wydajność fiskalną tego opodatkowania. Nie we wszystkich państwach władze samorządowe mają bowiem odpowiednie władztwo podatkowe, które pozwoliłoby na korzystanie z elastyczności opodatkowania dochodów i kształtowanie jego wydajności fiskalnej stosownie do potrzeb finansowych.

\section{Przegląd opodatkowania dóbr i usług}

Katalog podatków samorządowych związanych z opodatkowaniem towarów i usług jest bardzo szeroki. Obejmuje zarówno ogólny podatek od konsumpcji i sprzedaży, jak i selektywne podatki od konsumpcji oraz podatki związane z wykonywaniem przez samorząd terytorialny określonych czynności czy z umożliwieniem dostępu do pewnych towarów i usług.

W klasycznym ujęciu nakładanie ogólnego podatku od konsumpcji i sprzedaży - VAT - powinno należeć wyłącznie do kompetencji organów centralnych, które ustanawiają podstawę opodatkowania oraz stawki. VAT nie stanowiłby odpowiedniego podatku własnego samorządu terytorialnego, gdyby negatywnie wpływał na handel pomiędzy mniejszymi jurysdykcjami, stwarzał problemy związane z oszustwami podatkowymi czy generował wysokie koszty poboru i egzekwowania. Stąd w praktyce rola samorządu terytorialnego w przypadku VAT ogranicza się do udziału we wpływach z tego podatku ${ }^{69}$. Ponadto w niektórych państwach transfery międzysektorowe są częściowo oparte na dochodach z VAT.

68 The European..., s. 418 i 434.

69 M.F. Ambrosiano, M. Bordignon, op. cit., s. 327-328. 
Inaczej przedstawia się kwestia samorządowych podatków związanych z opodatkowaniem konsumpcji selektywnej. Ich zaletą jest możliwość prostego administrowania na poziomie lokalnym i powiązania ze świadczeniem określonych usług publicznych. Przykładowo opodatkowanie produktów tytoniowych czy alkoholowych może służyć sfinansowaniu zadań związanych z opieką społeczną, a koszty budowy i utrzymania dróg mogą być pokryte ze środków pochodzących z podatków nakładanych na pojazdy mechaniczne lub paliwa. Podatki te raczej nie zapewniają jednak odpowiednich wpływów budżetowych, które umożliwiałyby sfinansowanie lokalnych wydatków publicznych. Dlatego w większości państw samorządowe dochody z opodatkowania związanego z opodatkowaniem towarów i usług mają charakter uzupełniający wobec innych wydajniejszych źródeł opodatkowania (majątku i dochodów). Wśród analizowanych państw wyjątek stanowią Węgry, w których ponad 80\% dochodów podatkowych pochodzi właśnie z opodatkowania towarów i usług. Na Węgrzech bowiem najistotniejszym podatkiem samorządowym jest podatek lokalny od działalności gospodarczej, który jest nakładany na przedsiębiorstwa zlokalizowane lub zarejestrowane na terenie gminy i oparty na marży brutto ${ }^{70}$. Stawka jest ustalana przez gminę, ale nie może być wyższa niż $2 \%$.

O różnorodności źródeł samorządowego opodatkowania towarów i usług świadczą poniższe przykłady.

W Estonii na liście podatków, które można wiązać z opodatkowaniem towarów i usług, znajdują się: podatek od reklam, podatek z tytułu zamknięcia dróg i ulic, podatek od pojazdów mechanicznych, podatek od zwierząt, podatek od rozrywki i opłaty parkingowe. Przepisy ustawowe regulują nie tylko przedmiot opodatkowania, lecz także podmiot opodatkowania oraz zwolnienia. Władze lokalne mają natomiast prawo określenia stawki podatkowej, jak również zachęt i zwolnień, przy czym 75\% gmin nie nakłada żadnych z tych podatków, co może świadczyć o braku presji fiskalnej.

W Grecji podatki od towarów i usług obejmują: podatek od sprzątania ulic, podatek od oświetlenia ulicznego, podatek od piwa, podatek od reklamy ${ }^{71}$.

W Holandii do gminnych dochodów podatkowych, dla których źródłem opodatkowania są towary i usługi, należą podatki: turystyczny, od psów, z tytułu opłaty za ścieki i z tytułu opłaty za zanieczyszczenie wody ${ }^{72}$. Prowincje mają udział w podatku od pojazdów silnikowych, przy tym ten dodatek jest pobierany jednocześnie z komponentem krajowym tego podatku, ale w rzeczywistości jest to odrębne opodatkowanie. Niemniej jednak maksymalną stawkę komponentu regionalnego tego podatku ustala organ centralny.

Na Litwie wpływy samorządu terytorialnego związane z opodatkowaniem towarów i usług pochodzą z podatku od zanieczyszczeń i podatku od zasobów naturalnych. Podatek od zanie-

70 Podstawę opodatkowania stałej działalności handlowej stanowią przychody netto ze sprzedaży pochodzące z dostaw produktów i usług, pomniejszone o: wartość zakupu sprzedanych towarów, wartość usług pośrednich, opłaty podwykonawców za usługi, koszty materiałów oraz bezpośrednie koszty badań, badań stosowanych i eksperymentalnych prac rozwojowych zgłoszone w roku podatkowym. Zob. European Commission, op. cit.

71 OECD/UCLG, op. cit., Part III, Country profiles, Greece.

72 Ibidem, Part III, Country profiles, Netherlands. 
Tabela 4. Struktura dochodów podatkowych sektora samorządowego z opodatkowania towarów i usług w 2018 r.

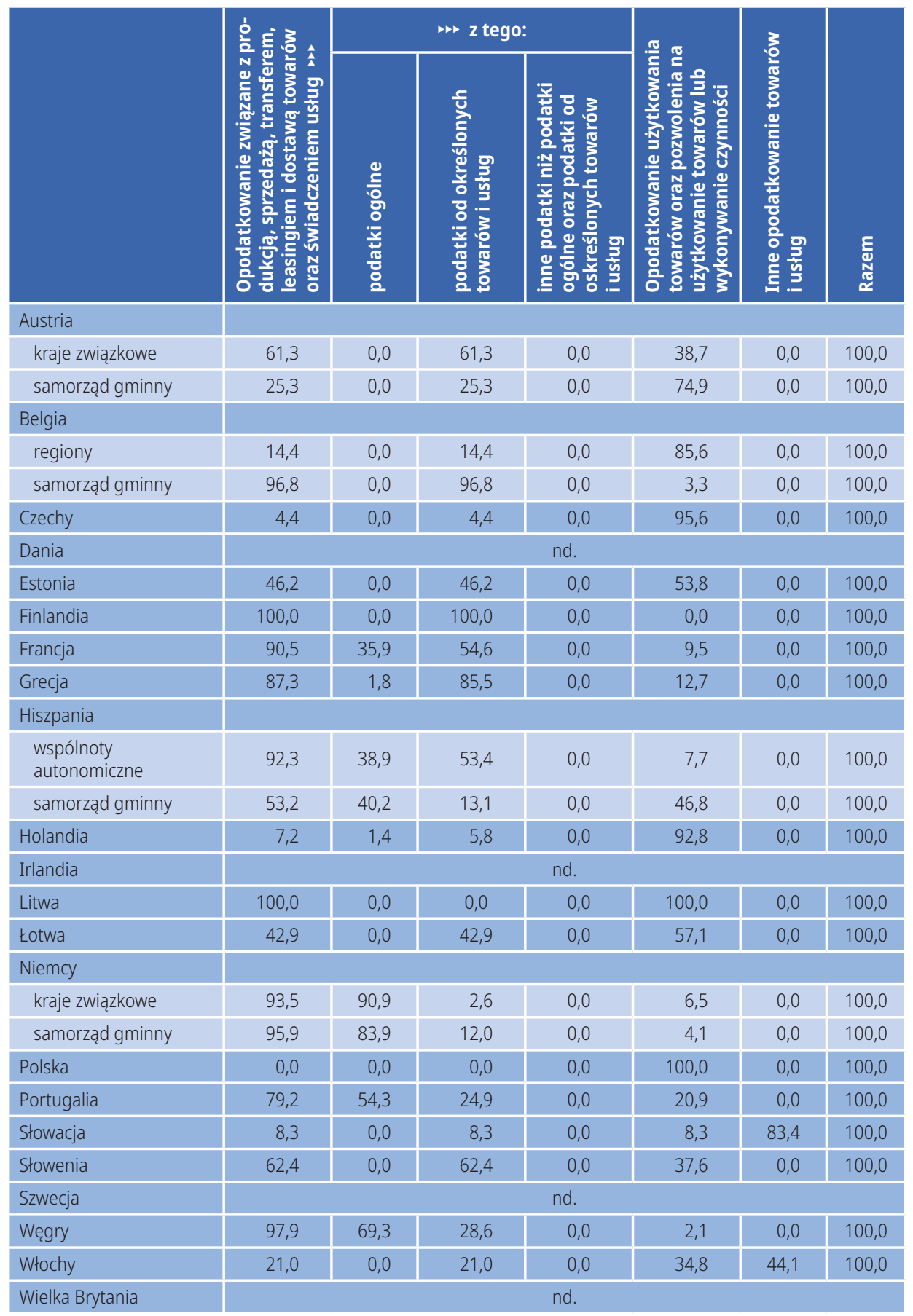

Źródło: opracowanie własne na podstawie OECD, op. cit. 
czyszczeń, z wyjątkiem zanieczyszczenia środowiska towarami lub odpadami opakowaniowymi, jest podatkiem dzielonym z rządem centralnym - 30\% trafia do budżetu państwa i jest przeznaczone na sfinansowanie inwestycji środowiskowych (program Litewskiego Funduszu Inwestycji Środowiskowych), 70\% jest zaś kierowane do budżetów gmin, w których występuje zanieczyszczenie, na sfinansowanie działań przewidzianych w specjalnym gminnym Programie Wspierania Ochrony Środowiska. Z kolei podatek od zasobów naturalnych jest dzielony między budżet państwa, do którego trafia 90\% podatku, a budżet gminy, na której terenie są wydobywane węglowodory i która otrzymuje $10 \%$ tego podatku ${ }^{73}$.

Na Łotwie samorządowe dochody podatkowe związane z opodatkowaniem towarów i usług mają charakter podatków dzielonych. Należą do nich podatki od zasobów naturalnych oraz podatek od loterii i gier hazardowych. Podatek od wydobywania surowców naturalnych lub zanieczyszczenia środowiska - z wyjątkiem wywozu odpadów i emisji dwutlenku węgla $\left(\mathrm{CO}_{2}\right)$ powyżej określonych limitów jest wpłacany w $60 \%$ do budżetu państwa, a w 40\% do budżetu gminnego. Z kolei 100\% wpływów z opodatkowania z tytułu wykorzystania użytecznych głębin podziemnych, wtłaczania do struktur geologicznych gazu ziemnego i stosowania substancji promieniotwórczych jest wpłacane do budżetu samorządu ${ }^{74}$. Alokacja dochodów z opodatkowania hazardu polega na przekazaniu 5\% do budżetu jednostki samorządu terytorialnego właściwej ze względu na lokalizację hazardu, a 95\% do budżetu państwa. Podatek od loterii o zasięgu krajowym powinien trafić do budżetu państwa, natomiast od loterii prowadzonej w skali lokalnej - do budżetu samorządu. Wszystkie wpływy z podatku związane z opodatkowaniem hazardu organizowanego za pośrednictwem telekomunikacji powinny zasilić budżet państwa ${ }^{75}$.

W Słowacji gminy mogą nakładać kilka specjalnych podatków lokalnych od towarów i usług, w tym: podatek od zakwaterowania, podatek od psów, podatek od pojazdów mechanicznych z tytułu wjazdu do historycznej części miasta i parkowania w niej pojazdu, podatek od obiektu jądrowego, podatek od rozrywki (podatek od niezarobkowych automatów do gry ${ }^{76}$ ), podatek od automatów sprzedających i podatek od użytkowania przestrzeni publicznej. Władze lokalne decydują o nałożeniu każdego z tych podatków oraz ustalają ich stawki, jak również mają dużą autonomię w zakresie ich podstawy opodatkowania (zwolnienia, obniżki stawek) ${ }^{77}$. W przepisach ustawowych wprawdzie określono stawki podatkowe dla tych danin, ale jednocześnie dopuszczono możliwość ustalenia przez organ administrujący podatkiem stawek niższych lub wyższych w zależności od sytuacji lokalnej i podano reguły pozwalające ustalić maksymalny wymiar stawki w odniesieniu do powszechnie obowiązujących przepisów ${ }^{78}$.

W Słowenii lista podatków związanych z opodatkowaniem towarów i usług jest stosunkowo krótka. Obejmuje bowiem głównie lokalny podatek turystyczny oraz podatek od gier hazar-

73 European Commission, op. cit.

74 Ibidem.

75 Ibidem.

76 Automaty do gry aktywowane lub obsługiwane w zamian za zapłatę, przy czym automaty te nie wypłacają żadnej wygranej finansowej i działają w publicznie dostępnych miejscach.

77 OECD/UCLG, op. cit., Part III, Country profiles, Slovak Republic.

78 Act No. 582/2004 Coll., op. cit. 
dowych. Na władzach centralnych ciąży obowiązek ustanowienia tych podatków, tym samym gminy nie mają prawa do określania ich stawek, podstawy opodatkowania ani ulg ${ }^{79}$.

Na Węgrzech poza wspomnianym podatkiem lokalnym od działalności gospodarczej istnieją inne drobne podatki związane z opodatkowaniem towarów i usług, np. gminny podatek turystyczny. Samorządy lokalne mają także prawo do części dochodów z podatku od pojazdów mechanicznych. Elementy konstrukcyjne tego podatku (stawki, podstawę opodatkowania i ulgi) ustanawiane są przez władze centralne, ale jego poborem zajmują się władze lokalne ${ }^{80}$.

\section{Podsumowanie}

Przeprowadzona analiza znaczenia samorządowych dochodów podatkowych oraz ich struktury w wybranych państwach członkowskich UE wskazuje na bardzo duże zróżnicowanie podatków samorządowych. Szczególne znaczenie w tym kontekście ma zasadnicza różnorodność systemów finansów publicznych państw europejskich pod względem zarówno decentralizacji finansów samorządu terytorialnego, jak i konstrukcji systemu podatkowego.

Zgodnie z Revenue Statistics 2020 udział samorządowych dochodów podatkowych w PKB oraz w dochodach podatkowych ogółem wśród państw europejskich jest najwyższy w państwach federalnych (Niemcy, Hiszpania) oraz w państwach skandynawskich (Dania, Finlandia, Szwecja), a najniższy w takich państwach, jak: Estonia, Czechy, Litwa, Słowacja, Irlandia i Grecja. Na nieco wyższym poziomie te relacje kształtują się w takich państwach, jak: Holandia, Austria, Wielka Brytania, Węgry, Portugalia i Słowenia. Natomiast Włochy, Polska, Francja, Belgia i Łotwa są państwami, w których wspomniany udział jest na średnim poziomie. Brak spójności klasyfikacyjnej wynikający z braku uniwersalnej i ujednoliconej definicji podatków samorządowych powoduje, że do interpretacji analizowanych dwóch wskaźników statystycznych należy podchodzić ostrożnie. Na bardziej kompleksowe porównanie samorządowych dochodów podatkowych w państwach europejskich pozwala jednak skonfrontowanie danych ilościowych z danymi jakościowymi opisującymi funkcjonowanie podatków samorządowych poszczególnych rodzajów.

Na podstawie dokonanej analizy można stwierdzić, że zgodnie z ustaleniami naukowymi opodatkowanie majątku, w tym przede wszystkim podatek od nieruchomości, stanowi niewątpliwie użyteczne źródło dochodów we wszystkich badanych państwach europejskich. Wpływy, które przynosi, są z jednej strony niezbędne do pokrycia wydatków samorządowych, ale z drugiej - zbyt niskie, aby w pełni sfinansować działalność samorządów. W tej sytuacji do zabezpieczenia odpowiednich środków na realizację zadań publicznych przez samorządy konieczne są wpływy z innych rodzajów podatków. W analizowanych państwach europejskich najczęściej źródłem kolejnych samorządowych dochodów podatkowych są dodatki lokalne/regionalne do opodatkowania dochodów osób fizycznych bądź udziały w ogólnokrajowych wpływach z tego podatku, a także szczególne opodatkowanie dóbr i usług. W licznej grupie omawianych państw to właśnie opodatkowanie dochodów jest najistotniejszym źródłem samorządowych dochodów

79 Local Public..., s. 183.

80 European Commission, op. cit. 
podatkowych. Lista takich państw byłaby jeszcze dłuższa, gdyby nie nieścisłości w klasyfikowaniu udziałów w ogólnokrajowych podatkach od dochodów, głównie osób fizycznych. Z kolei opodatkowanie towarów i usług w ramach podatków samorządowych w większości państw europejskich stanowi jedynie element uzupełniający dochody podatkowe.

Żadnemu z przeanalizowanych rozwiązań w zakresie funkcjonowania podatków samorządowych, obowiązujących w wybranych państwach europejskich, nie można dać pierwszeństwa. Niemniej jednak w kontekście krajowej dyskusji o potrzebie wypracowania nowego modelu finansowania jednostek samorządu terytorialnego przydatne - jako źródło inspiracji i wzorów mogą być pojedyncze rozwiązania przyjęte w poszczególnych państwach. Jednak przy przenoszeniu zagranicznych doświadczeń na grunt krajowy należy mieć na względzie, że konstrukcja i efektywność rozwiązań sprawdzających się w danym państwie zależy od wielu czynników, wśród których przede wszystkim można wskazać: zdolność władz samorządowych do administrowania podatkami, zakres usług publicznych finansowanych z samorządowych dochodów podatkowych oraz kulturę podatkową państwa, a nawet określonych regionów.

Z perspektywy liczby zadań wykonywanych przez samorząd terytorialny w Polsce, zwłaszcza przez gminy, i w świetle poczynionych ustaleń najkorzystniejsze byłoby oparcie ewentualnego nowego modelu finansowania jednostek samorządu terytorialnego na licznych źródłach opodatkowania. Poszczególne formy opodatkowania powinny zostać tak dobrane, aby zapewniły wzrost wydajności fiskalnej podatków lokalnych. Ponadto można by również wziąć pod rozwagę rozszerzenie władztwa podatkowego władz samorządowych, tak aby zostały zwiększone możliwości bezpośredniego oddziaływania jednostek samorządu terytorialnego na ich sytuację budżetową.

\section{Bibliografia}

Ambrosiano M.F., Bordignon M., Normative Versus Positive Theories of Revenue Assignments in Federations [w:] Handbook of Fiscal Federalism, red. E. Ahmad, G. Brosio, Edward Elgar, Cheltenham-Massachusetts 2006.

Bird R.M., Rethinking Subnational Taxes. A New Look at Tax Assignment, „IMF Working Paper” 1999, nr 165, https:// doi.org/10.5089/9781451858037.001.

Bird R.M., Bahl R., Subnational Taxes in Developing Countries. The Way Forward, „IB Paper" 2008, nr 16.

Blöchliger H., Petzold O., Finding the Dividing Line Between Tax Sharing and Grants. A Statistical Investigation , „OECD Working Papers on Fiscal Federalism" 2009, nr 10, https://doi.org/10.1787/5k97b10wbnw-en.

Błaszko A., Organizacja samorzqdu terytorialnego oraz nadzoru nad samorzq̨dem we Francji, „Finanse Komunalne" 2019, nr 6.

The European Tax Handbook, red. M. Alvarado et al., IBFD, Amsterdam 2019.

Federalizm fiskalny w teorii i praktyce, red. K. Piotrowska-Marczak, Difin, Warszawa 2009.

Guziejewska B., Normative Versus Positive Approach to Fiscal Decentralisation and the Measures of Decentralisation. An Analysis Based on the Example of Selected Countries of Central and Eastern Europe " Comparative Economic Research" 2018, t. 21, nr 1.

Hammar H., Wüthrich-Pelloli U., Local and Regional Democracy in Belgium, Council of Europe, 27 ${ }^{\text {th }}$ Session, Strasbourg, 14-16 October 2014, CG(27)7FINAL, https://rm.coe.int/168071a308\#_Toc391652445. 
Husson J.F., Mahieu C., Sägesser C., Federalism and Decentralisation in Belgium [w:] The Palgrave Handbook of Decentralisation in Europe, red. J.M. Ruano, M. Profiroiu, Palgrave Macmillan, Cham 2017.

Johansen H.B., Doganoglu G., Local Democracy in Slovenia, Council of Europe, 35 $5^{\text {th }}$ Session, Strasbourg, 6-8 November 2014, CPL35(2018)03final, https://www.coe.int/en/web/congress/35th-session-documents.

Kim J., The Role of Intergovernmental Fiscal Institutions. The Case of Tax Sharing [w:] Institutions of Intergovernmental Fiscal Relations. Challenges Ahead, red. J. Kim, H. Blöchliger, OECD Publishing, Paris 2015, https://doi. org/10.1787/9789264246966-3-en.

Kopyściańska K.A., Podatek katastralny w kontekście konstytucyjnej zasady sprawiedliwości, „Annales Universitatis Mariae Curie-Skłodowska. Sectio H. Oeconomia" 2016, t. 50, nr 1.

Local Public Finance in Europe. Country Reports, red. R. Geißler, G. Hammerschmid, Ch. Raffer, Bertelsmann Stiftung, Gütersloh 2019.

Rubolino E., The Efficiency and Distributive Effects of Local Taxes: Evidence from Italian Municipalities, Institute for Social and Economic Research, University of Essex, Essex 2019.

\section{Akty prawne, dokumenty}

Act No. 582/2004 Coll. on Local Taxes and Local Fee for Municipal Waste and Minor Construction Waste, as amended, https://www.mfsr.sk/en/taxes-customs-accounting/direct-taxes/local-taxes/local-taxes-local-fee-municipal-waste-minor-construction-waste-act-582/2004-coll/.

European Commission, Taxes in Europe Database v3, https://ec.europa.eu/taxation_customs/tedb/taxDetails. html?id=205/1577833200\#footnote1.

OECD, Revenue Statistics 2020, https://doi.org/10.1787/8625f8e5-en.

OECD/UCLG, Subnational Governments Around the World. Structure and Finance, Barcelona 2016, https://www. uclg.org/sites/default/files/global_observatory_on_local_finance_0.pdf.

Rahandusministeerium, Personal Income Tax, https://www.rahandusministeerium.ee/en/tax-and-customs-policy/taxes.

Republic of Lithuania Law on the Approval of Financial Indicators of the State Budget and Municipal Budgets for 2019, http://finmin.Irv.lt/uploads/finmin/documents/files/2018-12-11\%20XIII-1710.pdf. 